\title{
MASTER
}

DOE/NASA CONTRACTOR REPORT

DOE/NASA CR-150532

\section{APPLICATION OF SOLAR ENERGY TO AIR CONDITIONING SYSTENS}

Prepared by

IBM Corporation

Federal Systems Division

Huntsville, Alabama 35805

Under Contract NA S8-32036 with

National Aeronautics and Space Administration

George C. Marshall Space Flight Center, Alabama 35812

for the Department of Energy

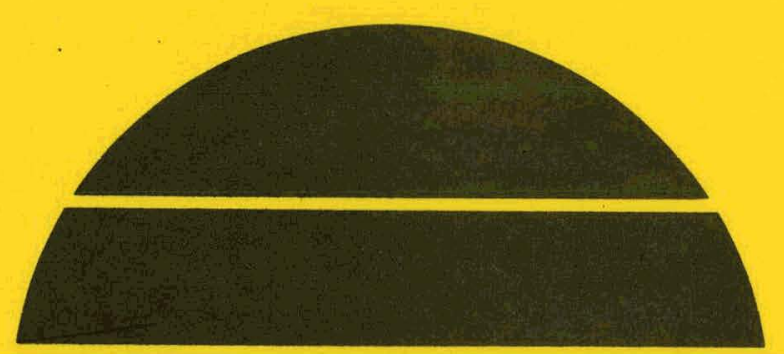

\section{U.S. Department of Energy}




\section{DISCLAIMER}

This report was prepared as an account of work sponsored by an agency of the United States Government. Neither the United States Government nor any agency Thereof, nor any of their employees, makes any warranty, express or implied, or assumes any legal liability or responsibility for the accuracy, completeness, or usefulness of any information, apparatus, product, or process disclosed, or represents that its use would not infringe privately owned rights. Reference herein to any specific commercial product, process, or service by trade name, trademark, manufacturer, or otherwise does not necessarily constitute or imply its endorsement, recommendation, or favoring by the United States Government or any agency thereof. The views and opinions of authors expressed herein do not necessarily state or reflect those of the United States Government or any agency thereof. 


\section{DISCLAIMER}

Portions of this document may be illegible in electronic image products. Images are produced from the best available original document. 
NOTICE

This report was prepared to document work sponsored by the United States Government. Nelther the United States nor 1ts agents the United Statas Department of Energy, the United States National Aeronaut 1 s and Space Administration, nor any federal employees, nor any of their contractors, subcontractors or the1r employees, make any warranty, express or implied, or assume any legal liabllity or responsibility for the accuracy, completeness, or usefulness of any information, apparatus, product or process disclosed, or represent that its use would not infringe privately owned rights. 
TECHNICAL REPORT ST ANDARD TITLE PAGE

\begin{tabular}{|c|c|}
\hline $\begin{array}{l}\text { 1. REPORT NO. } \\
\text { DOE/NASA CR-150532 }\end{array}$ & 3. RECIPIENT'S CATALOG NO. \\
\hline \multirow{2}{*}{$\begin{array}{l}\text { 4. TITLE AND SUBTITLE } \\
\text { Application of Solar Energy to Air Conditioning Systems }\end{array}$} & $\begin{array}{l}\text { 5. REPORT DATE } \\
\text { NOVEMber } 1976\end{array}$ \\
\hline & 6. PERFORMING ORGANIZATION CCIDE. \\
\hline $\begin{array}{l}\text { 7. AUTHOR(S) } \\
\text { Jonathon M. Nash and Andrew J. Harstad }\end{array}$ & $\begin{array}{l}\text { B. PERFORMING ORGANIZATION REPOR T } \\
\text { IBM REpOrt } 76 \mathrm{~W}-0122\end{array}$ \\
\hline $\begin{array}{l}\text { 9. PERFORMING ORGANIZATION NAME AND ADORESS } \\
\text { IBM Cornoration }\end{array}$ & 10. WORK UNIT NO. \\
\hline Federal Systems Division & $\begin{array}{l}\text { 11. CONTRACT OR GRANT NO. } \\
\text { NAS 8-32036 }\end{array}$ \\
\hline Huntsville, Alabama 35805 & \multirow{2}{*}{$\begin{array}{l}\text { 13. TYPE OF REPORi \& PERIOD COVERED } \\
\text { Contractor Report }\end{array}$} \\
\hline \multirow{2}{*}{$\begin{array}{l}\text { 12. SPONSORING AGENCY NAME AND ADDRESS } \\
\text { National Aeronautics and Space Administration } \\
\text { Washington, D. C. } 20546\end{array}$} & \\
\hline & 1.1. SPONSORING AGENCY CODE \\
\hline
\end{tabular}

15. SUPPLEMENTARY NOTES

This work was accomplished under the technical management of Mr. Earle G. Harris, Marshall Space Flight Center, Alabama 35812.

16. ABSTRACT

The results of a survey of solar energy system applications of air conditioning are summarized. Techniques discussed are both solar powered (absorption cycle and the heat engine/Rankine cycle) and solar related (heat pump). Brief descriptions of the physical implications of various air conditioning techniques, discussions of status, proposed technological improvements, methods of utilization and simulation models are presented, along with an extensive bibliography of related literature.

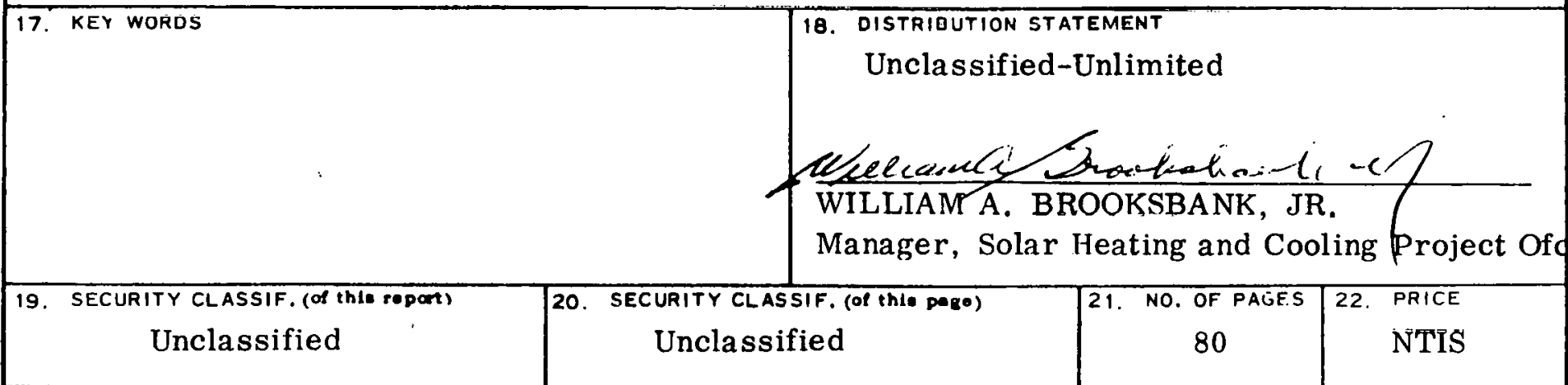


THIS PAGE

\section{WAS INTENTIONALLY LEFT BLANK}




\section{TABLE OF CONTENTS}

Page No.

Abstract

i

List of Tables/Illustrations iv

\section{SECTION}

1.. Introduction and Summary 1

2. Absorption Cooling 6

2.1 Lithium Bromide-Water Cycle 9

2.2 Ammonia-Water Cycle 12

3. Heat Engine/Rankine Cycle Cooling 13

4. Heat Pump System 16

5. Discussion and Conclusions 21

5.1 Potential Advantages 21

5.2 Potential Disadvantages 22

5.3 Technological Improvements Trend 25

APPENDIX

A. Solar Energy Air Conditioning Bibllography 27

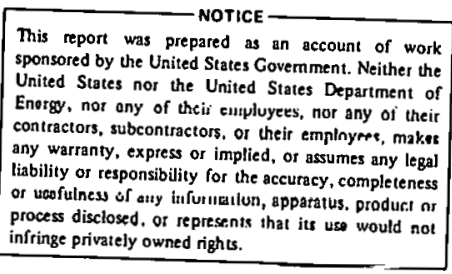




\section{TABLES/ ILLUSTRATIONS}

Table

I

II

III

IV

V

VI

Figure

2.1

2.2

3.1

4.1
Title

Page

Potential Advantages of Solar A1r Conditioning Applications

Potential Disadvantages of Solar Air Conditioning Applications

Technological Improvements Trend

5

Comparison of Solaire (Arkla Industries)

Three Ton Air Conditioning Units

Heat Pump Heat Sources and Sinks

18

Common Heat Pump Types

19

Page

Absorption Cooling Cycle

8

Performance Map of Solaire (Arkla Industries) Three Ton Air Conditioning Units

11

15

20 
INTRODUCTION AND SUMMARY

This report summarizes the results of a survey of solar energy system applications of air conditioning. This effort was conducted in support of IBM's system analysis activities which are a part of the Systems integration of Marketable Subsystems program at Marshall Space Flight Center in Huntsville, AL. $:$ This review has been primarlly directed toward those air conditioning techniques deemed most likely to find residential application in the near (5-year) term and which are compatible with the solar energy systems expected to result from this program.

The air conditioning techniques discussed are both solar powered (absorption cycle and the heat engine/Rankine cycle) and solar related (heat pump). However, it should be recognized that other methods exist and their omission is not intended to indicate other than the selection criteria described above. Among those omitted are such techniques as: absorptive humidification/ dehumidification cycles, rock bed regeneration and nocturnal radiation.

The basic phenomena utilized in absorption air conditioning is similar to that of the heat engine/Rankine cycle and the heat pump in that they each derive their refrigeration effect from the condensation and evaporation of a refrigerant liquid. The essential difference is that the necessary pressure differential within the absorption cycle is provided by a physico-chemical process where the others depend on mechanically operated compressors. This is an advantage as pumping the refrigerant in the form of a refrigerant-absorbent solution requites far less mechanical energy than compressing it as a vapor. Each of these cycles depends on an energy source. The absorption cycle and heat engine/Rankine cycle use heat as their energy source; the heat pump uses electricity.

Subsequent sections present brief descriptions of the physical implications of various air conditioning techniques. Also presented are discusstons of status, proposed technology improvements, methods of utilization, and simulation models. 
The general conclusion of the studies reviewed is that the application of solar energy to atr conditioning systems is an interesting and potentially economically viable concept. However, both the solar powered and the solar related techniques are inherently more complex than standard solar heating systems. Resulting advantages and disadvantages are summarized in Tables I and II. Trends in system technological improvements are summarized in Table III. 


\section{TABLE I}

POTENTIAL ADVANTAGES OF SOLAR AIR CONDITIONING APPLICATIONS

- Year-round utflization improves "heating only" load factor

- Less severe storage requirements than heating due to load more nearly in phase with avallable energy

- Consumer usage/demand amount and percentage of energy consumption is growing rapidiy

- Reduction of seasonal summer utility peaking

- Low cost increases over conventional heat powered systems

- Generally favorable cost/performance ratio for commercial applications

- Existing detalled simulation capabilities 


\section{TABLE II}

POTENTIAL DISADVANTAGES OF SOLAR AIR CONDITIONING APPLICATIONS

- "In building" heat losses are detrimental both to system performance and amount of road

- High performance collectors, high temperature storage, and specialized high technology equipment are all high cost items

- Further extension of technology is hampered by thermodynamic limitations

- Operation of collectors at elevated temperature levels reduces effictency

- Absorption auxiliary energy mode is less efficient and more costly than competitive systems

- Solar air conditioning is new, different and generally unavailable

- Support services are more technical and more frequent

- Outdoor cooling tower is generally required

- Unfavorable cost/performance ratio for residential solar powered applications

- Rankine cycle and heat pump use flurocarbons for operation

- Load management is critical for efificient operation

- Detafled simulation cost 
TABLE III

TECHNOLOGICAL IMPROVEMENTS TREND

- Increase performance by elevating solar heat supply temperature

- Development of techniques with auxiliary energy mode economically comparable with competitive systems

- Cold storage with excessive capacity and/or off peak operation

- Development of higher efficiency heat pumps by using variable speed and compression ratio, larger heat exchangers, and more efficient motors and compressors

- Near term improvements expected in reliability first, then efficiency

- Identification of dual source heat pumps as technically viable 


\subsection{ABSORPTION COOLING}

The most common approach to alr-conditioning applications of solar energy uses the absorption air conditioner in conjunction with solar collection and storage subsystems. This would be expected, as the best developed conventional heat-actuated cooling technique today is the absorption cycle.

The absorption cycle (simplified by omission of various heat exchangers) is schematically represented in Figure 2.1 as a series of pressure and heat exchange processes. Heat energy is input to the cycle at the generator. This heating separates the high-pressure, dilute refrigerant-absorbent solution into refrigerant vapor and concentrated (i.e., refrigerant free) solution. The hot, high pressure concentrated solution is used to preheat the entering dilute solution and then returned to the absorber through a pressure reduction valve. The hot, high pressure refrigerant vapor enters the condenser where it is condensed to a liquid by rejection of heat to cooling water. The cooled liquid then enters the evaporator at low pressure by passing through an expansion valve. The absorption cycle cooling effect is achieved by the endothermic evaporation process which returns the refrigerant liquid to a vapor. The low pressure refrigerant vapor leaves the evaporator and enters the absorber where it is reabsorbed into the concentrated solution returning from the generator. The heat of absorption is rejected to cooling water and the now dilute refrigerant-absorbent solution is pumped back to the generator. Variation of this procedure include: (1) using ambient air rather than water for cooling, (2) adding a liquid refrigerant recirculation pump to the evaporator, and (3) using low pressure levels in the cycle and eliminating the solution pump by substitution of a heat-actuated vapor lift procedure.

Design constraints of practical solar energy applications of absorption cycles are primarily caused by thermal limitations. These are the thermodynamic properties of the refrigerant-absorbent solution and the effectiveness of heat transfer equipment in the absorption air conditioner. The upper thermal limits of non-pressurized liquid storage and reduced efficiency with elevated temperature of solar collectors serve to compound these limitations. The result of these factors is the trend toward use of improved heat exchangers and a requirement for recirculation of the cooling water through an outdoor cooling tower for heat rejection. 
Economic application of absorption cycle cooling is limited by cost of equipment and cost of operation in the auxiliary. (non-solar powered) mode. Manufacturers in both the United States and Japan are actively striving to reduce equipment cost. The auxiliary mode operation however, is expected to be the long term limitation to use of the absorption cycle in residential cooling applications.

Simulation of performance of an absorption cycle cooler can be achieved by empirical representation of the unit's operating characteristics based on manufacturer test data. Such a representation is compatible with the modular format required for subsystem simulation by TRNSYS. TRNSYS, the industry standard computer simulation program for solar energy systems, is written to accept user developed modules of this nature. The required data for an absorption machine is a performance map of delivered capacity as a function of (1) hot water, condensing water and chilled water flow and temperature conditions and (2) the rejected heat rate. As both the $\mathrm{LiBr}-\mathrm{H}_{2} \mathrm{O}$ and the $\mathrm{NH}_{3}-\mathrm{H}_{2} \mathrm{O}$ cycles are functionally as shown by Figure 2.1, they each meet these modeling requirements.

Absorption air conditioners and associated cooling towers are more expensive to purchase than vapor compression air conditioners of the same capacity. In residential applications this first cost differential has proven to be detrimental to consumer acceptance. Exceptions to this lack of acceptance exist only where low-cost natural gas was available as an alternative to high-cost electricity. For these conditions, or where low-cost waste heat can be used, operating costs of the absorption unit is lower cost than for vapor compression. Where electricity is relatively inexpensive and fuel is reasonably expenstve, the electric vapor compression machine is superior.

This section presents a brief discussion of two closed-loop, cooling cycles which are heat-actuated and based on absorption of refrigerant in liquid absorbent solutions. The first is 11 thium bromide-water $\left(\mathrm{LiBr}-\mathrm{H}_{2} \mathrm{O}\right)$ where water is the refrigerant and the other is ammonia-water $\left(\mathrm{NH}_{3}-\mathrm{H}_{2} \mathrm{O}\right)$ where ammonia is the refrigerant. In both cases solar energy is used to supply the heat energy to the generator of the absorption unit. 


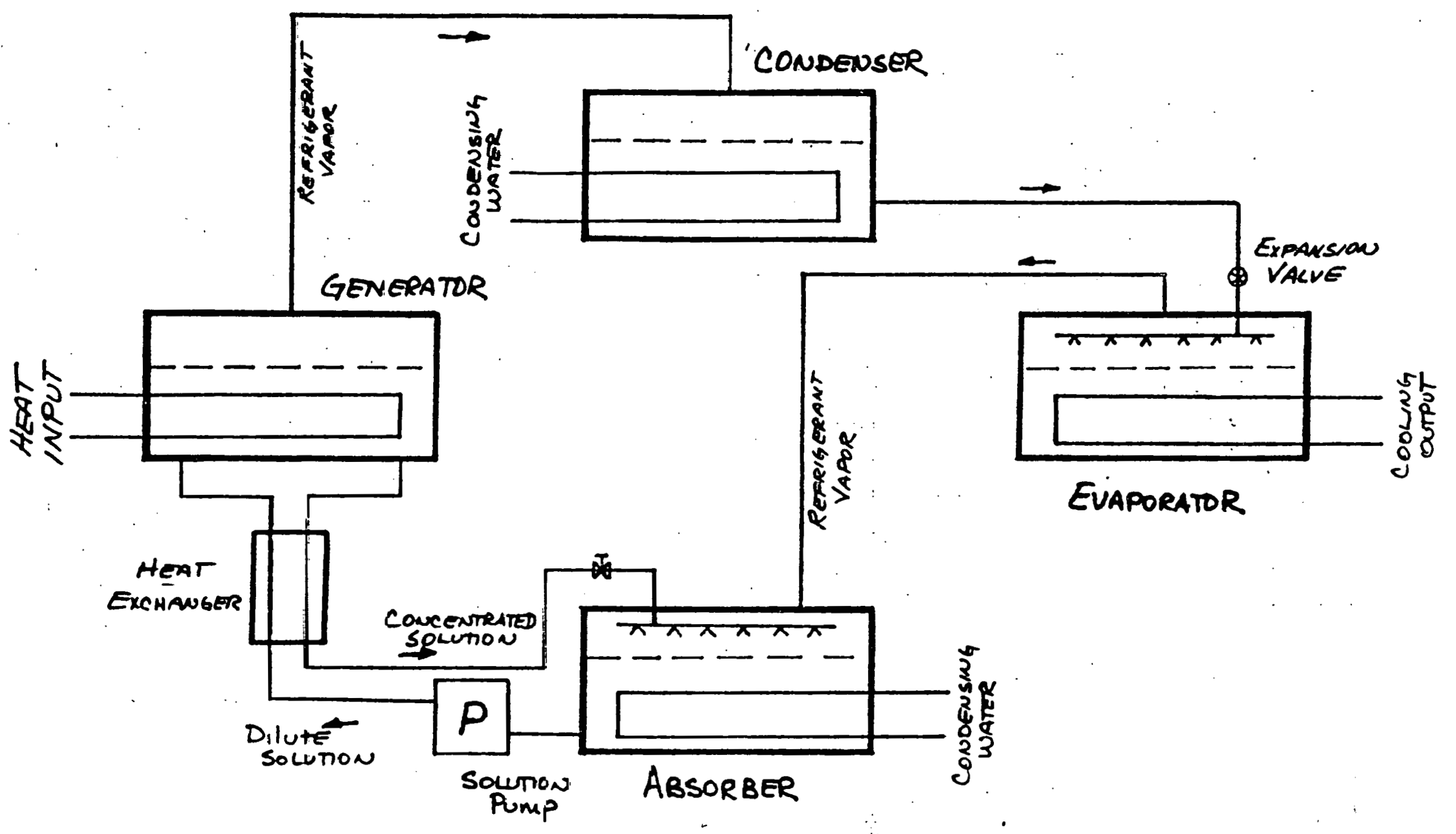

Figure 2.1. Absorption Cooling Cycle 


\subsection{LITHIUM BROMIDE - WATER CYCLE}

Most solar energy cooling applications to date have used the $\mathrm{LiBr}-\mathrm{H}_{2} \mathrm{O}$ absorption cycle with water cooled absorber and condenser. This cycle is also the most common conventional cooling application of an absorption cycle technique. This popularity is primarily due to two thermodynamic characteristics of the $\mathrm{LiBr}-\mathrm{H}_{2} \mathrm{O}$ cycle compared with the $\mathrm{NH}_{3}-\mathrm{H}_{2} \mathrm{O}$ cycle. These are: (1) lower generator temperature and (2) lower cycle working-fluid pressure levels. The first characteristic allows operation with generator temperatures of $170-210^{\circ} \mathrm{F}$ versus $205-250^{\circ} \mathrm{F}$ for water cooled and $260-$ $340^{\circ} \mathrm{F}$ for air cooled $\mathrm{NH}_{3}-\mathrm{H}_{2} \mathrm{O}$ cycles. The second characteristic allows operation with reduced pumping power.

Arkia Industries has selected this cycle to market for solar energy applications of their absorption machines. They presently have two water fired absorption air conditioning units for use in solar energy installations. These units are the 3-ton 501-WF and the 25-ton WF-400.

Residential application of the 3-ton unit has been limited mainly to research and demonstration projects. A new model 3-ton unit WF-36 is scheduled for volume production and general avallability in early 1977. A comparison of the operating characteristics of the two 3-ton models is shown in Table IV and Figure 2.2. The data required for simulation of the WF-36 unit is given in Table V. A Model of the earlier 3-ton unit is contained in the standard TRNSYS library. 


\begin{tabular}{|c|c|c|}
\hline \multicolumn{3}{|c|}{$\begin{array}{l}\text { COMPARISON OF SOLAIRE (ARKLA INDUSTRIES) } \\
\text { THREE TON AIR CONDITIONING UNITS } \\
\text { NOTE: } 501-W F \text { is Liq/Air and WF-36 is Liq/Liq }\end{array}$} \\
\hline CRITERIA/MODEL $\quad \therefore \cdot$ & $36(W F-36)$ & $501-W F$ \\
\hline DESIGN DELIVERIED CAPACITY, BTUH & 36,000 & 36,000 \\
\hline \multicolumn{3}{|l|}{ ENERGY REQUIREMENTS } \\
\hline DESIGN HOT WATER INPUT, BTUH & 50,000 & 55,000 \\
\hline DESIGN HOT WATER INLET, ${ }^{\circ} \mathrm{F}$ & 195 & 210 \\
\hline PERMISSIBLE RANGE OF INLET, ${ }^{\circ} \mathrm{F}$ & $170-205$ & $180-210$ \\
\hline DESIGN HOT WATER FLOW, GPM & 11.0 & 11.0 \\
\hline PRESSURE DROP O $11 \mathrm{GPM}, \mathrm{FT} \mathrm{H}_{2} \mathrm{O}$ & 9.8 & 4.6 \\
\hline MAX. PERMISSIBLE FLOW, GPM & 22 & 22 \\
\hline STD ELECTRICAL VOLTAGE, $60 \mathrm{~Hz}, 1-\emptyset$ & 115 & 115 \\
\hline WATTAGE DRAW & 250 (MAX) & 450 (TYP) \\
\hline \multicolumn{3}{|l|}{ CONDENSING WATER DATA } \\
\hline DESIGN HEAT REJECTION, BTUH & 86,000 & 91,000 \\
\hline DESIGN INLET TEMP., ${ }^{\circ} \mathrm{F}$ & 85 & 85 \\
\hline PERMISSIBLE RANGE OF INLET, ${ }^{\circ} \mathrm{F}$ & $75-90$ & $70-85$ \\
\hline DESIGN FLOW, GPM & 12.0 & 10.0 \\
\hline PRESSURE DROP @ DESIGN, FT $\mathrm{H}_{2} \mathrm{O}$ & 9.6 & 4.0 \\
\hline MAX. PERMISSIBLE FLOW, GPM & 25 & 17.5 \\
\hline
\end{tabular}




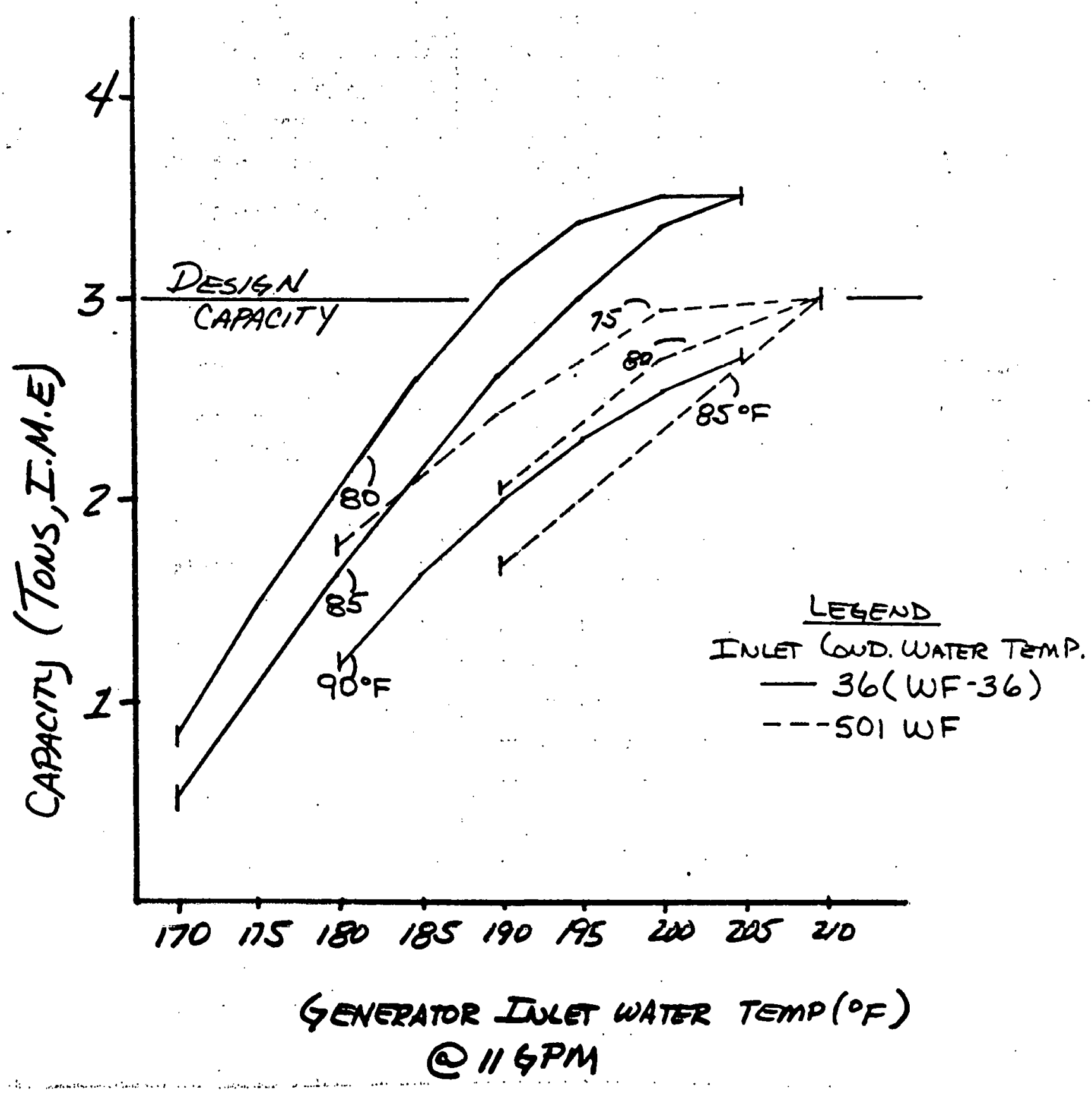

Figure 2.2. Performance Map of Solair (ARKLA Industries) Three Ton Air Conditioning Units 


\subsection{AMMONIA - WATER CYCLE}

The ammonia-water cycle is essentially identical of the $\mathrm{LiBr}-\mathrm{H}_{2} \mathrm{O}$ cycle. The principal exception is the addition of a rectifier between the generator and the condenser. This rectifier prevents water vapor from entering the condenser since, unlike the $\mathrm{L} i \mathrm{Br}-\mathrm{H}_{2} \mathrm{O}$ cycle, water is not the refrigerant. Because of the high working pressures, mechanical pumps are always required to return the dilute solution from the absorber to the generator.

Only limited solar energy system applications of $\mathrm{NH}_{3}-\mathrm{H}_{2} \mathrm{O}$ cycle cooling have been made. The general opinion is that high (over $200^{\circ} \mathrm{F}$ ) generator temperature requirements ammonia-water cycle coolers exclude operation with flat plate collectors. Contrasting with this almost universal conclusion, researchers at the University of Florida report operation with hot water supplies in the $135^{\circ}$ to $180^{\circ} \mathrm{F}$ range. The reason for this disagreement has not been fully determined by this review. However, indications are that higher concentrations of ammonia in the refrigerantabsorbent solution may be the answer. 


\subsection{HEAT ENGINE/RANKINE CYCLE COOLING}

The most promising solar powered air conditioning alternative to the absorption cycle is the heat engine/Rankine cycle combined with the conventional vapor compression cooling cycle. The Rankine cycle is used to convert solar energy into mechanical energy and thus provide the compressive force needed in the system. Problems associated with this technique are primarlily those of the heat engine. Cooling by vapor compression is well established.

The Rankine cycle and vapor compression cycle are schematically represented in figure 3.1 as a coupled series of pressure and heat exchange processes: Heat energy is input to the Rankine cycle at the boller. This function is similar to that of the absorption cycle generator except that instead of separating a refrigerant-absorbent solution into a vapor and a solution it converts a pure refrigerant solution entirely into a refrigerant vapor. The refrigerant commonly used is Freon. The hot refrigerant vapor enters the high-pressure inlet of the heat engine's turbine where it expands and produces rotary motion. Still warm, the low-pressure vapor then enters the condensor where it is condensed to a liquid by rejection of heat to cooling water. The liquid refrigerant is then pumped back to the boller. This portion of Figure 3.1 represents the Rankine cycle used to provide rotary motion from solar energy and thus function as a heat engine.

The rotary output of the heat engine is used to provide mechanical input to the compressor. The compressor is used to raise the very-low pressure of the vapor refrigerant from its evaporator outlet condition to the same pressure level as the turbtne expander outlet. The combined vapor flows into the condenser as described above. The vapor compression cycle shown is at a lower pressure than the Rankine cycle. After being condensed to a liquid, that portion of the refrigerant used for cooling is then further expanded through an expansion valve and then enters the evaporator at still a lower pressure. The vapor compression cycle cooling effect is achleved oy the endothermic evaporation process which returns the refrigerant liquid 
to a vapor. This very low pressure refrigerant vapor leaves the evaporator and enters the low-pressure inlet of the compressor where it is compressed to a pressure compatible to the turbine expander outlet. This portion of Figure 3.1 represents the vapor compression cycle used to convert rotary motion into a cooling effect and thus provide air conditioning. Conventional application of this cycle uses an electric motor to provide the rotary motion.

Many attempts are currently being made to improve the performance of the basic heat engine/Rankine cycle. The most common is using the warm outlet refrigerant vapor from the turbine expander to preheat the liquid. refrigerant between the pump and the boiler inlet.

Simulation of performance of heat engine/Rankine cycle cooler can be achieved by emperical representation of the unit's operating characteristics by the method described in Section 2.0. The performance data required is of the same form as that described for the absorption cycle.

Although not presently available in the HVAC market, heat engine/Rankine cycle coolers are expected to become commercially available with in the next five years. Their purchase price is expected to be comparable with today's absorption coolers. As such, they would have a higher purchase price than conventional equipment. However, unlike the absorption units, they are adaptable to auxiliary energy input in the form of rotary motion instead of heat. This allows use of an electric motor which reduces the auxillary mode operating conditions to the same as conventional. The greatest appeal of this concept is not having the auxiliary mode economic penalty of the absorption cycle and thus being a potential candidate for residential application. 


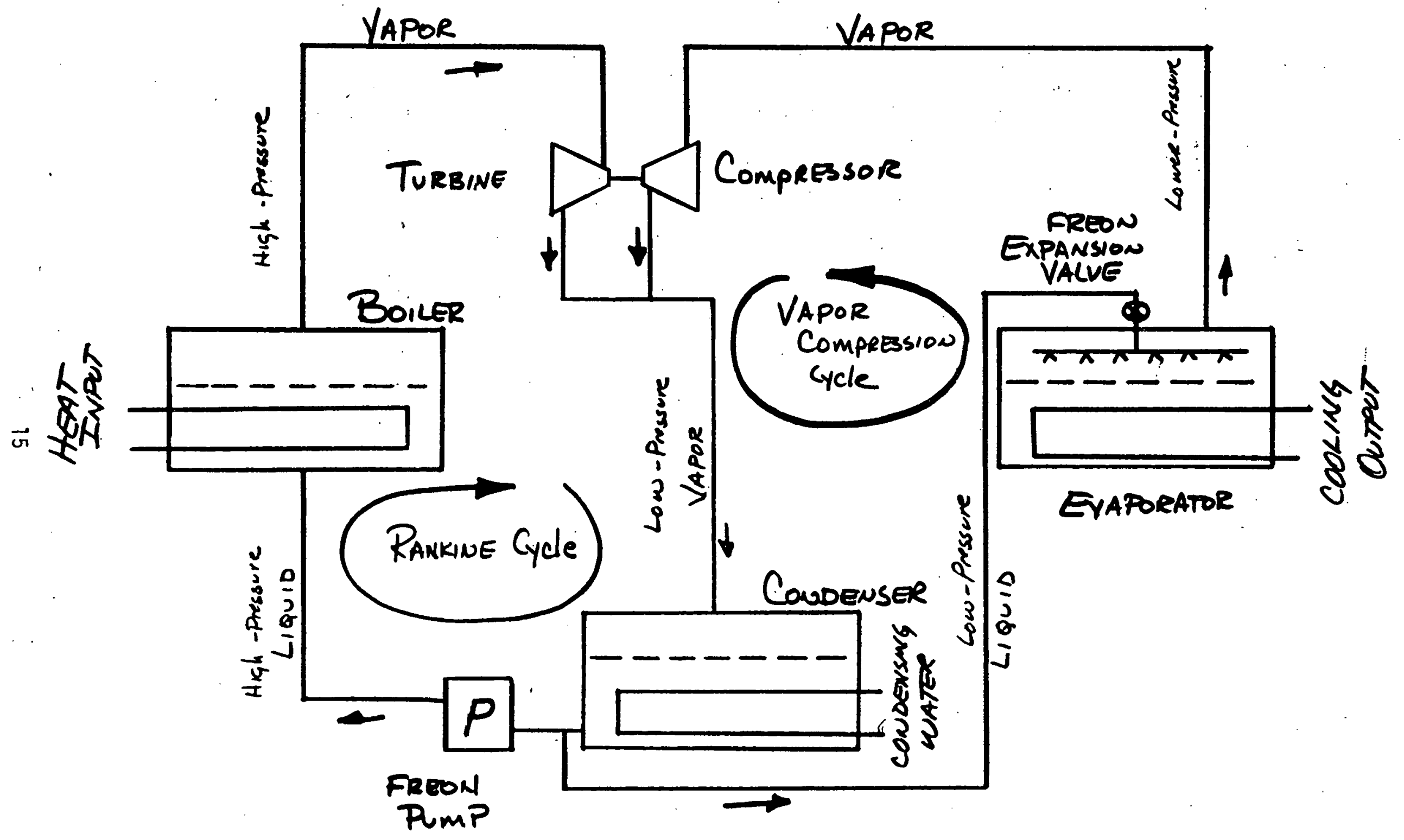

Figure 3.1. Heat Engine/Rankine Cycle Cooling 


\subsection{HEAT PUMP SYSTEMS}

Heat pumps are considered in this solar air conditioning review al though they neither derive their operating energy from solar provided heat nor actively interface with the solar energy system while providing cooling. However, they are related since heat pumps have been used as an auxiliary heat source for solar heating systems which can also provide the entire cooling requirement. The cooling method is the conventional vapor compression cycle described in the last section.

Heating with a conventional heat pump is accomplished by reversing the roles of the condenser and evaporator. This rejects the heat of condensation into the area being heated and takes in ambient heat by the endothermic evaporation process. The compressor serves to raise the refrigerant temperature level between ambient and the desired heating temperature.

Heating with a solar-heat pump has been considered in three configurations. These are: (1) in parallel with the solar heating system which uses an amblent temperature heat sink as described above for the conventional case, (2) in series with solar storage tank heat source, and (3) with capability of dual source where the choice of heat sink can be made by comparison of temperature level and the highest is chosen. As with conventional applications of heat pumps, each of these solar configurations require an auxiliary (usually electric resistance heaters) heat source.

For the cases described various ambient media are used for the heat source. The selection for a particular application is determined from considerations of geographic location, climate, cost avallability, and type of structure. A comparison of these sources as summarized by ASHRAE is shown in Table $V$. As indicated, solar heat provides an excellent source when it is avallable. This is because it is at a relatively high temperature which increases the performance capablifty of the heat pump. A further benefit of the solar-heat pump system versus a solar heating system without a heat pump is reduction of the required collector temperature. This can provide an increase of collector efficiency and capacity. 
Types of solar heat pump systems are classified as direct and indirect. Direct systems use a solar collector/evaporator combination. This is usually designed with no cover plates so it can also be used as a condensor by rejecting heat when in the cooling cycle. Table VI shows various common heat pump types. The circuit used in the direct solar heat pump system may resemble that shown for the earth-to-air heat pump.

Indirect systems employ another fluid to collect heat by circulation through the solar collector. This heated fluid is then used to heat the refrigerant by passage through a heat exchanger. When air is the heated working fluid the first system shown in Table 4.2 for air-to-air may be used. When water is used, either the water-to-alr or water-to-water type may be employed. A dual source indirect solar assisted heat pump system is shown schematically in Figure 4.1.

Simulation of performance of solar heat pump systems can be achieved by utilization of the standard TRNSYS 1ibrary heat pump model. This model can be used for any of the three characteristic types and is devised to accept user-specified performance data from which it derives off-design operational characteristics. The data required are heat added, heat rejected, and total work input over a spectfied range of source or sink temperatures. Such data are available from the manufacturers of heat pumps which might be selected.

Studies of these configurations have shown solar heat pump systems to be economically feasible throughout much of the United States. The dual source evaporator configuration has been shown superior to either the series or parallel system. Unfortunately, although recognized as analytically desirable, there has not been, as far as can be determined, any residential dual source heat pumps manufactured to date. 
Table V. Heat Pump Heat Sources and Sinks

\begin{tabular}{|c|c|c|c|c|c|c|c|}
\hline Hoot Source & Air & City Woter & Wot hioler & Surfoce Waler & Wasto Waler & Earth & Solor \\
\hline Source classificialion & Primary & Prinary or auxiliary & Primary & Primar; & Primary or auxiliary & Primary or auxiliary & Auxiliary \\
\hline $\begin{array}{l}\text { Suitabitity as beat } \\
\text { sink }\end{array}$ & Good & Good & Good & Good & Variable with source & Usually poor & $\begin{array}{l}\text { May be used to dissipate } \\
\text { heat to air }\end{array}$ \\
\hline $\begin{array}{l}\text { Availability } \\
\text { (location) }\end{array}$ & Universal & Cities & Uncertain & Rare & Limited & Exterisive & Universal \\
\hline $\begin{array}{l}\text { Availability } \\
\text { (time) }\end{array}$ & Cuntinusus & $\begin{array}{l}\text { Conitinuous-except } \\
\text { local shoriages }\end{array}$ & $\begin{array}{l}\text { Continuous-acheck wa- } \\
\text { ter table: }\end{array}$ & Continuous & Variable & $\begin{array}{l}\text { Continuous, temper: } \\
\text { ture drops as heat is } \\
\text { remowed, slowly rises } \\
\text { when pump stops }\end{array}$ & $\begin{array}{l}\text { Intermittent, unpredict- } \\
\text { able, except over ex- } \\
\text { rended time }\end{array}$ \\
\hline $\begin{array}{l}\text { Expense } \\
\text { (original) }\end{array}$ & $\begin{array}{l}\text { Low, less than earth and } \\
\text { water scurces except } \\
\text { city }\end{array}$ & Usually lowest & $\begin{array}{l}\text { Variable, depending on } \\
\text { cost of drilling well }\end{array}$ & Low & Variable & High & High \\
\hline $\begin{array}{l}\text { Expense } \\
\text { (operating) }\end{array}$ & Refatively low & $\begin{array}{l}\text { High, usually prohibi- } \\
\text { tive }\end{array}$ & Low to maderste & Relatively low & Low & Relaively moderate & $\begin{array}{l}\text { Unexplored. Promising } \\
\text { as auxiliary for reduc- } \\
\text { ing operating cost }\end{array}$ \\
\hline $\begin{array}{l}\text { Temperature } \\
\text { (level) }\end{array}$ & $\begin{array}{l}\text { Favorable } 75-95 \% \text { of } \\
\text { time in mosi of } \\
\text { United States }\end{array}$ & Lsuafly satisfactory & Satisfactory & Salisfactory & Ustrally good & $\begin{array}{l}\text { Initially good-drops } \\
\text { with time and race of } \\
\text { heal withdrawal }\end{array}$ & Excellent \\
\hline $\begin{array}{r}\text { Temperature } \\
\text { (variation) }\end{array}$ & Extreme & $\begin{array}{l}\text { Virriable with location } \\
\text { (10 to } 25 \mathrm{f} \mathrm{deg})\end{array}$ & Small & Moderate & Usually moderate & $\begin{array}{l}\text { Large-less than for air, } \\
\text { however }\end{array}$ & Extreme \\
\hline Design information & Usually adequate & Usually adequate & Usually adequzte & Usually adequate & $\begin{array}{l}\text { Adequate if source is } \\
\text { constant in supply } \\
\text { and temperature }\end{array}$ & Inadequatc & Practically available \\
\hline Size of equipmint & Moderate & S.nall & Small (excepl for well) & Small & $\begin{array}{l}\text { Variable (usually mod. } \\
\text { erale) }\end{array}$ & $\begin{array}{l}\text { Small (except ground } \\
\text { coi's) }\end{array}$ & Available in some areas \\
\hline $\begin{array}{l}\text { Adaptability to } \\
\text { stiandard product }\end{array}$ & $\begin{array}{l}\text { Excellent, can be factory } \\
\text { assemblec and tested }\end{array}$ & Encellent & $\begin{array}{l}\text { Excellent kexcept for } \\
\text { well) }\end{array}$ & Excellent & Poor & Poor & Poor \\
\hline $\begin{array}{l}\text { Sources it may aug. } \\
\text { ment }\end{array}$ & & Air, earth & & & & . & \\
\hline Special problems & 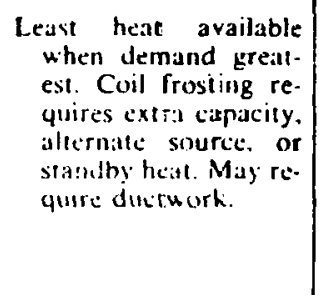 & 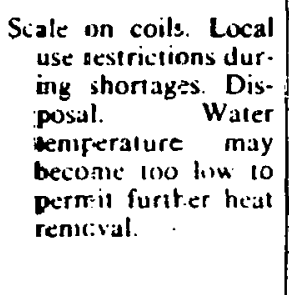 & $\begin{array}{l}\text { Corrosion, scade may } \\
\text { form on heat truasser } \\
\text { surface. Disposal may } \\
\text { require second well. } \\
\text { Water locsticin, tem- } \\
\text { perature, oomposition } \\
\text { usually uaknown un- } \\
\text { til well drilled. Well } \\
\text { may run dry. }\end{array}$ & $\begin{array}{l}\text { Water may cause } \\
\text { scale, corrosioni } \\
\text { and algae foul- } \\
\text { ing. }\end{array}$ & $\begin{array}{l}\text { Usually scale forming or } \\
\text { corrusive. Ofien in- } \\
\text { sufficient supply. } \\
\text { Very limited appliza- } \\
\text { tion, hence required } \\
\text { individual design } \\
\text { Freeze-up hazards. }\end{array}$ & $\begin{array}{l}\text { Limited by local } \\
\text { geo:ogy and climate. } \\
\text { Installation costs } \\
\text { diffeult to estimate. } \\
\text { Requires considerable } \\
\text { ground area. may } \\
\text { darrage lawns, gar- } \\
\text { dens. Leaks difficult } \\
\text { to repair. }\end{array}$ & $\begin{array}{l}\text { Probably will require } \\
\text { heal storage equip- } \\
\text { ment at either } \\
\text { evaporator or con- } \\
\text { denser side. }\end{array}$ \\
\hline
\end{tabular}


Table VI. Common Heat Pump Types

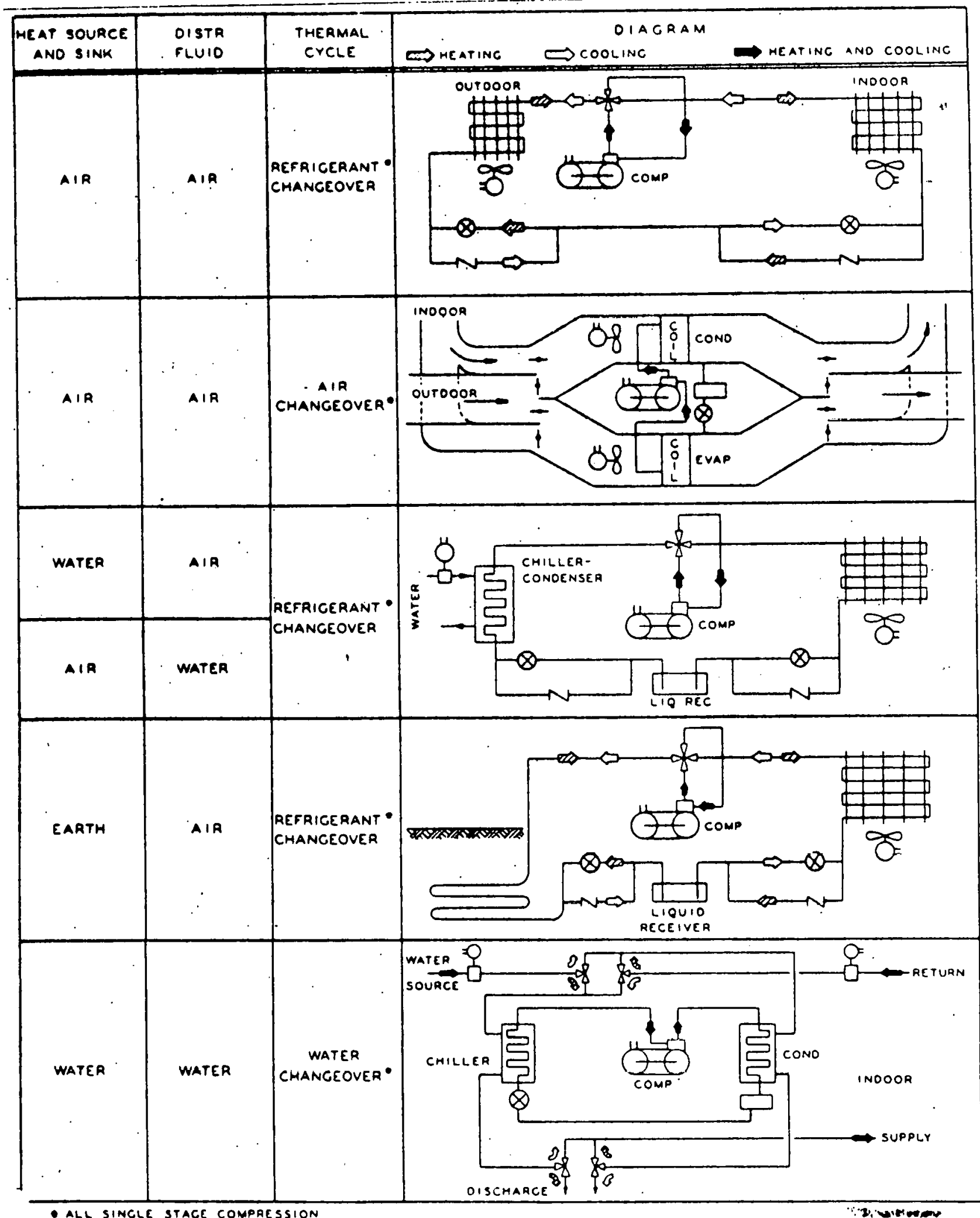

(From ASHRAE Systems Handbook, 1976) 


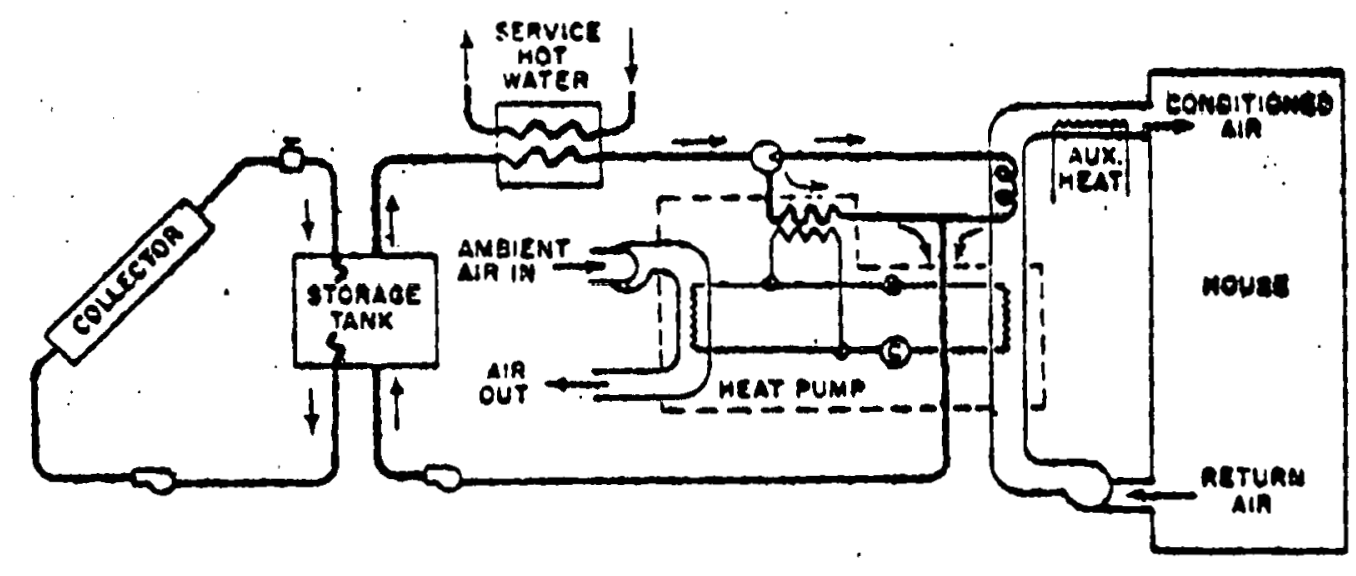

Figure 4.1. Dual Source Solar Assisted Heat Pump (From Duffie and Beckman, 1976a) 


\section{DISCUSSION AND CONCLUSIONS}

Application of solar energy to air conditioning systems is an interesting and potentially economically viable concept. The techniques which have emerged from this survey have demonstrated many conditions for which air conditioning requirements and solar energy system capabilities are closely matched. However, both the solar powered and solar related cooling techniques presented are inherently more complex than standard solar heating systems. This complextty places even more emphasis on both performance and economic considerations for proper evaluation. This section presents some of these considerations and their impact on successful application.

\subsection{POTENTIAL ADVANTAGES}

Systems which address both heating and cooling requirements generally have year-round utilization. This improves the load factor experfenced by the heating only system as the solar equipment is used in the summer cooling season as well as the winter heating season. The exact degree to which the combined heating and cooling system is uttlized depends on the spectfic location and requirements.

Heating systems using solar energy find their greatest loads occurs during the night, This puts constraint on storage subsystem capabllity. Cooling load normally is greatest in the day. This presents less severe storage requirements since it is more in phase with the avallability of solar energy source.

Both the amount of energy required to provide residential air conditioning and the percentage of energy consumed nationally that it represents are growing rapidly. This condition serves to place additional emphasis on all renewahle energy source techniques which can provide air conditioning and thus emphasis on solar applications. 
In some regions of the country, utilities experience higher demands for energy on a seasonal basis. To the extent that this peaking is attributed to air conditioning and the cooling can be provided by solar energy, the uttlity load can be leveled. This benefit is viable only when the impact of auxiltary energy requitrements are properly considered.

In some applications, normally commercial, the conventional method of atr conditioning uses heat powered cooling equipment. In these cases, the increased system cost of adding solar energy as an additional heat source is usually very competitive.

In general, commercial applications offer alternatives for air conditioning system design which make solar energy attractive. Examples of these can be: cooling loads for longer during the year, avallability of waste heat, load size that justify larger expenditure for slightly more efficlent equipment and the many other reasons that absorption cycle air conditioning is widely used in many many conventional commercial applications today.

Finally, the abllity to simulate solar afr conditioning systems to a detail. sufficient to optimize design and operating conditions is avallable today for both the solar powered and the solar related methods. This ability allows in-depth understanding of the system implications of combining solar energy and conventional technology into a workable solution for reduced fossel fuel dependence.

\subsection{POTENTIAL DISADVANTAGES}

Common design practice for solar energy space heating systems which have the storage subsystem in the building being heated is to ignore heat loss from storage and transport loops. This is because the energy loss is assumed to offset a portion of the heating load requirement. In hot water only systems such losses must be considered in evaluation of the solar energy system design as they represent inefficiencies of conversion of collected energy into tts intended purpose. Air conditioning with solar energy has an even more severe problem with storage and transport losses. When attempting to satisfy a space cooling load these losses are both a reduction in capability and an increase in required load. This double 
penalty means that greater care in design and greater cost in storage and transport subsystems are needed for solar powered air conditioning than for solar heating.

Both the absorption cycle and Rankine cycle/heat engine performs better at higher temperatures. Their operation at the upper thermal limits of most flat plate collector-water storage systems is not optimum. The increase in efficiency of the solar powered cooling equipment at higher temperature and the corresponding decrease in flat plate collector efficiency creates a system condition which compromises both. This conflict can be reduced by use of high performance collectors, high temperature storage techniques, and other specialized equipment. The limitation is that all of these improvements cost more than the basic system. There is a definite economic penalty to provide energy at higher temperatures. The closer to ambient conditions, the cheaper the energy.

Although methods exist to raise the operating temperature levels in the solar powered cooling systems, there are only limited benefits to be gained. Thermodynamic limitations on the systems and their basic technology are such that greatly increased efficiencles are not expected for the cooling techniques discussed. This is true regardless of future development efforts.

One basic thermodynamic limitation to higher temperature operation is collector heat loss. Collectors are able to convert only a portion of the solar energy that they recelve into useful heat. This ability (or efficlency) is related to the heat loss from the collector due to temperature difference between the collector and its surroundings. The greater the temperature difference, the greater the loss. The higher the operating temperature level, the greater the difference, and the less efficient is the collector. Improvements in collector design (such as evacuated tube collectors) can reduce this effect but these have had a higher cost/performance ratio than good flat plate collectors. 
Most economically optimized solar powered air conditioning systems do not have the capacity to meet the entire cooling load. The comparative inefficiency of absorption cycle coolers operating in the auxiliary (non-solar powered) mode versus conventional electrical powered coolers is a serious drawback for economic residential utilization of absorption cycle techniques.

All solar powered air condition systems represent a new concept for the HVAC industry. As such, rapid acceptance should not be expected.

Further resistance to acceptance is the general lack of commercially available "offthe-shelf" hardware. Thus, even if a typical engineer, architect, or homebuilder desired to include solar air conditioning in a structure the required equipment would not be found in their normal distribution and supply outlets. The National Demonstration Plan is expected to reduce this barrier, but it still exists today.

Increased complexity of the solar air conditioning system versus the conventional system and the decreased reliability associated with newly developed equipment indicates more frequent servicing of a more technical (and costly) nature would be expected.

An outdoor tower is required when water is used for cooling. The $\mathrm{LiBr}-\mathrm{H}_{2} \mathrm{O}$ and lower temperature $\mathrm{NH}_{3}-\mathrm{H}_{2} \mathrm{O}$ absorption cycles must have water cooling to operate. Although the Rankine cycle/heat engine concepts reviewed do not all require a cooling tower as such, the ones which showed greatest promise efther did or else had a similar approach. Example of the latter was a system using an evaporative condenser. This concept requires ducting of ambient air over the condenser of the Rankine cycle and providing cooling by evaporation of water sprayed on the condenser colis. The performance is the same as for the cooling tower, but cost-Trade studies indicate a possible improvement over the cooling tower approach. 
Residential applications of absorption units have been shown to be generally economically unfeasible for solar energy systems. The near term prospects of the Rankine cycle/heat pump do not indicate that it. will be economically competitive either. The general conclusion is that these solar powered techniques have an unfavorable cost/performance ratio when compared to conventional electrical powered air conditioners under near term economic conditions.

Both the Rankine cycle and the heat pump use flurocarbons (such as Freon) for working fluid. Increasing environmental concerns over release of flurocarbons into the atmosphere (through leaks, etc.) could prove to be a limitation to these systems as they are now designed.

The high cost of solar air conditioning equipment and the sensitivity of its performance to operating conditions place critical importance on load management. This importance indicates the need for well engineered control systems controlling well understood equipment.

Although existing detailed simulation techniques exist which can provide analysis of each of the cooling methods discussed, the computational cost of such simulation is significant.

\subsection{TECHNOLOGICAL IMPROVEMENTS TREND}

The general trend for solar air conditioning systems is to raise the overall operating temperature. This is accomplished by elevating solar heat supply temperature by efther using larger collector arrays and reducing the collector loop flow rates or by higher technology collectors.

The high penalty of auxiliary mode fuel cost for absorption cycle systems is the main driver for the heat engine/Rankine cycle. This is because the auxiliary mode for the latter is identical to conventional cooling systems which can be 3 to 4 times as efficient as the absorption cycle. 
In all cases described, start up conditions are less' efficient than steady state. Greater efficiency is also found when the avaflable energy is used when collected rather than stored and used later. These conditions are met by using cold storage to accept excess capacity and off peak operation of the cooling units. The latter is primarily useful for the heat pump system.

Proposed improvements for solar heat pumps have included development of higher efficiency by using varlable speed and compression ratio, larger heat exchangers, and more effictent motors and compressors.

Even with all the proposed technological changes, practicality dictates that the expected big improvements in solar air conditioning will first be seen in increased system reliabllity. Later developments are expected to show increased efficiency.

The single greatest near term improvement from a technological and economic viewpoint is the encouragement of heat pump manufacturers to commercially produce a dual source residential heat pump. The technology is there. What is needed is for it to be done as soon as possible. 
APPENDIX

SOLAR ENERGY AIR CONDITIONING

BIBLIOGRAPHY 
Adler, S.; Levite, G.; Tabor H., "Altenkirch Solar-Cooled House". Proceedings of the UN Conf. on New Sources of Energy. Vol. 6, -- 60-65. New York; UN., 1964.

Adsett, E.E.; Gunn, A.W.; Ireton, V.M. "Solar Heating and Cooling in a Commercial Building". In "Sharing the Sun! Solar Technology in the Seventies. Vol. 3"; Boer, K.W. (Ed.). pp 343-355. 1976.

Akopdzhanyan, E.S., "Solar Air Conditioning Using Solid Absorbents", Appl. Solar Energy (USSR) (Engl. Trans1.); 5: No. 2, 55-58, 1969.

Akopozhanyan, E.S., "Solar Air Conditioning with Solid Absorbents", Appl. Solar Energy (USSR) (Eng1. Trans1.); 3: No. 6, 97-100, 1967.

Alcone, J.M., "Low Cost Solar Augmented Heat Pump System for Residential Heating and Cooling", ASME Winter Annual Meeting, Houston, Tex., Nov. 30 Dec. 4, '75, 15 p., 1975.

Allen, R., "Optimization Studies of Solar Powered Absorption Air Conditioning Systems", From Proceedings of the Solar Heating and Cooling of Buildings Workshop, Wash., DC, Mar 21-23, '73, Part 1: Technical Sessions, 21 Mar. 173.

Allen, R.W., "Optimization Study of Solar Absorption Air Conditioning Systems Semiannual Progress Report, 15 Aug - 15 Feb. '74", 1974.

Allen, R.W.; Anand, D.K., "Parametric Study of a Dynamic Solar Powered Absorption Cycle", In "Sharing The Sun! Solar Technology in the Seventies. Voi. 3"; Boer, K.W. (Ed.), pp 27-43, 1976.

Allen, R. (Ed.), "Proceedings of the Solar Heating and Cooling for Buildings Workshop, Washington, DC, March 21-23, '73. I. Technical Sessions" National science Fndtn., Washington, DC, Jul. '73, 536 p., Jul. '73.

Allen, R., "Proceedings of the Solar Heating and Cooling for Buildings Workshop, Part 2 Panel Sessions, March 23, '73", Dept. of Mech. Engineering, Maryland Univ., College Park, MD., Apr. '74. 65 p., Apr. ' 74.

Allen, R.W.; Morse, F.H.; Egrican, A.N., "Thermodynamic and Heat Transfer Analysis of Solar. Absorption Atr Conditioning Cycles", in 1975 Intn'1. Solar Energy Cong. and Expo. pp 394-395, $28 \mathrm{Jul} .175$.

Anderson, B.; Coonley, D., "An Ecologic Solar Heated and Cooled Home", Proceedings of 21 st Annual Technical Meeting, Institute of Environmental Sciences, Anaheim, CA, April 14-16, 175, Vo1. 1, pp 206-210, (A75-34926 16-31) Mount, Prospect, IL, Institute of Env. Sciences, Apr. 175.

Anderson, H., "Assessment of Solar Powered Vapor Jet Air-Conditioning Systems", In 1975. Intn's. Solar Energy Cong. and Expo. pp 408A-409, 28 Jul 175. 
Anderson; L.B.; Rauch, H.E., "Application of Optimization Techniques to Solar Heating and Cooling", American Astronautical Society and American Institute of Aeronautics and Astronautics, Astrodynamics Specialist Conference, Nassau, Bahamas, Jul 28-30, '75, AAS Paper 75-108; 36p., Jul. ' 75.

Anderson; L.B.; Winn, C.B.; Johnson, G.R., "Solar Heating and Cooling of the Santa Clara Community Center", in 1975 Intn'1. Solar Energy Cong. and Expo. pp. 308-309, 28 Jul. ' 75.

Anon., "A Real Solar House", Build. Syst. Des.; 72: No. 5, 10-12, 1975.

Anon., "Al1 Run By Sunshine", Engineering; 189: No. 4912, 804, 10 Jun. '60.

Anon., "Assessment of Solar-Powered Cooling of Buildings. Final Report", Hittman Assoc., Inc., Columbia, MD., Contract NSF C-858. 201p. (HIT-600), Apr. ' 75.

Anon., "Decade 80 Solar Home Designed to Achieve Climate Control with the Sun", Fueloil 0il Heat; 34: No. 4, 44-5, Apr. '75.

Anon., "Definition Report--National Solar Energy Research, Development and Demonstration Program", Div. of Solar Energy, ERDA, Washington, DC, 76p., Jun. ' 75.

Anon., "Development of A Solar-Powered Residential Air Conditioner. Final Summary Report", Airesearch Mfg. Co., Torrance, CA (Avail. NTIS), 1975.

Anon., "Development of A Solar-Powered Residential Air Conditioner. Screening Analysis", Contract NAS8-30758 for MSFC; Garrett Airesearch Manufacturing Co., pf Calif., July 25, 175 .

Anon., (NASA, MSFC, Huntsville, AL, "Development of A Solar-Powered Residential Heating and Cooling System", NASA-TM-X-70089, 10 May :74.

Anon., "Development of Solar Engineering In the USSR", Foreign Tech. Div., Wright-Patterson AFB, Ohio, Jul.' 74.

Anon., "Energy Conservation with Solar Climate Control", Arthur D. Little, Inc., Cambridge, MA. vp, 1973.

Anon., "Feasibility Demonstration of A Solar Powered Turbo-Compressor Air Conditioning and Heating System. Quarterly Progress Report No. 3 for the Period Dec. 16, '74 to Mar. 15, '75", NO. Contract NSF-C903. 28p.

Anon., "Federal Office Building, Saginaw, Michigan", Gen. Srv. Adm., Washington, DC, 52p (Avail. NTIS), Jul. '75.

Anon., "Federal Office Building, Saginaw, Michigan. Draft Environmental Impact Statement", Gen. Srv. Admin., Washington, DC, 52p. (Avail NTIS), JuT. ' 73. 
Anon., "Formulation of A Data Base for the Analysis, Evaluation, and Selection of A Low Temperature Solar Powered Air Conditioning System. Quarterly Progress Report, Oct. 31, '73 - Jan. 31, '74', Eng'ng. and Ind'1. Exp. Station, Florida Univ., Gainesvilile, FL; 184p., 31 Jan. ' 74.

Anon., "Harnessing the Sun's Energy for Heating and Cooling", NASA/MSFC, Huntsville, $A L, 6 p$.

Anon., "Honeywell Mobile Lab Studies Solar Heating and Cooling", Fueloil 0il Heat, 34: No. 3, 40, 45, Mar. ' 73.

Anon., "Interim Performance Criterla for Solar Heating and Combined Heating/ Cooling Systems and Dwellings", HUD; NBS, Dept. of Comm. (1 Jan. '75) 110p., 1 Jan. ' 75.

Anon., "Interim Performance Criteria for Commercial Solar Heating and Combined Heating/Cooling Systems and Facilities", NASA, MSFC, Huntsville, AL, (Avail. NTIS), 120p., Féb. 28, '75.

Anon., "Japanese/United States Symposium on Solar Energy Systems. Vol. 1 Summary of Proceedings", Mitre Corp., Washington, DC, (Ava 11. NTIS) 1974.

Anon., "Manhattan Site for Solar Air Conditioning Test", Energy Intl.; 12: No. 7, 27 (Jul. '75), Jul. '75.

Anon., "Market Potential for Solar Heating and Cooling in Buildings", Terrestrial Application of Solar Technology and Research (TERRASTAR). Final Report. p.13, Sep. ' 73.

Anon., (Mech. Contractor; 65: No. 4, 29-31; 50, "Massachusetts Institute of Technology Solar House IV", Apr. ' 58.

Anon., "National Program for Solar Heating and Cooling (Residential and Commercial Applications)", Div. of Solar Energy, ERDA, Washington, DC, 83p., Oct.' 75.

Anon., "National Plan for Solar Heating and Cooling (Residential and Commercial Applications). Interim Report", Div. of Solar Energy, ERDA, Washingtun, DC. , 121 p., Mar. 175.

Anon., "Proceedings of the 9th Intersociety Energy Conversion Engineering Conference", ASME; New York, NY, 1343p., 1974.

Anon., "Proceedings of the United Nations Conference on New Sources of Energy, Rome, Italy, 21-31 August, 1961. Voluem 6. Solar Energy: III.", United Nations; New York, 454p. (1964) (Conf-61080 1-p6), Aug.' 61.

Anon., "Project Plan for A Program to Develop A Solar Climate Control Industry", Arthur D. Little, Inc.; Cambridge, MA, vp., 1973. 
Anon., "Record of The 10th Intersociety Energy Conversion Engineering Conference", IEEE; New York, NY, 1557p., 1975.

Anon., "Research and Development Project for New Energy Technology (Sunshine Plan)", Leo Kanner Assoc., Redwood City, CA, 779p. (Translated from The Japanese).

Anon, "Rock Bed Regenerative Cooling", Heat. Vent. Engr.; 41: No. 490, 567569, May ' 68.

Anon., "Solar Air Conditioning with Film and Foam", Mod. Plast; 51: No. 2, p43, Feb. ' 74.

Anon., "Solar Climate Control: Status Report 1975", Arthur D. Little, Inc., Cambridge, MA, 30p, 1975.

Anon., "Solar Community Systems Analysis Projects", Sandia Labs, Albuquerque, NM, Contract AT(29-1)-789, 50p, (Avail. NTIS), Jul. ' 75.

Anon., "Solar Demonstration Project", Burt, Hill, And Associates, Architects; Butler, PA (nd), 6p.

Anon., "Solar Energy: A Dream. Becomes A Reality", Mech. Engineering; pp69-71, Feb. ' 75 .

Anon., "Solar Energy Applications. Papers Presented at The Symposium at the ASHRAE Annual Meeting, Montreal, Canada, June 23-27, 1974, New York; ASHRAE, Inc., 52p. (Conf-7406100-), 1974.

Anon, "Solar Energy Evaluation Group Report", Argonne National Lab, (Aug. '73), Contract W-31-109-ENG-38, 48p.

Anon., "Solar-Energy for Heating and Cooling", Committee on Science and Astronautics, US House of Rep., Washington, DC, 295p, GPO, 1973.

Anon., "Solar Energy for Heating and Cooling. Hearings before the 93rd Congress, First Session, U.S. House of Rep., Committee on Science and Astronautics, Subcommittee on Energy", Congressional Committee Print No. 13, Washington, DC, 291 p. (1973), GPO, 1973.

Anon., "Solar Energy Home Design in Four Climates", Harrisville, NH; Total Environmental Action, 208p., 1975.

Anon., "Solar Energy May Achieve Wide Use by 1980's", Chem. Eng. News; 51 : No. $5,12-13,29$ Jan. ' 73 .

Anon., "Solar Energy: Proof of Concept Experiments. Final Report", Mitre Corp., McLean, VA, Contract NSF-C831, vp., Dec. ' 73. 
Anon., "Solar Energy Research", Heat. Air Cond. J.; 43: No. 513, 36-37 (Aug. '74), Aug. '74.

Anon., "Solar Energy Research Information Meeting of NSF-RANN Grantees", National Center for Energy Management and Power, Philadelphia, PA. (Avai). NTIS), Mar. ' 73.

Anon., "Solar Energy Research Programs Alternatives", Mitre Corp., Dec. '73.

Anon., "Solar Energy's Role in Heating and Cooling of Buildings", ASHRAE J.; Special Issue About Solar Energy, Sep. 174.

Anon., "Solar Energy Utilization for Heating and Cooling", ASHRAE Handbook of Applications. New York; ASHRAE (1974), pp 59.1-59.20., 1974.

Anon., "Solar Energy Utilization for Heating, Cooling, Distillation and Drying", Heat., Piping Air Cond.; 30: No. 5, 147-52 (Jun. '58), Jun. '58.'

Anon., "Solar Feasibility Study for IBM - Preliminary Report", Smith, Hinchman \& Gryils Associates, Inc., Detroit, MI, 38p., Aug. 29, 17.

Anon., "Solar Heated and Cooled Office Building for the Massachusetts Audubon Society: Initial Planning and Design", Cambridge, Mass.; Arthur D. Little, Inc., 58p. (Avail. NTIS), Jun. '73.

Anon., "Solar Heating and Cooling Buildings", Terrest. Appl. of Solar Techn. and Res (TERRASTAR): Auburn Univ., Auburn, Ál, 1974.

Anon., "Solar Heating and Cooling Buildings. Final Report", Terr. Appl. of Solar Techn. and Rsrch. (TERRASTAR); Auburn Univ., Auburn, AL, Sep. 13.

Anơn., "Solar Heating and Cooling of Buildings Study Conducted for Department of The Army. Vol. I Executtve Summary and Implementation Plans., General Electric Co., Space Div., Philadelphia, PA (Avail. NTIS).

Anon., "Solar Heating and Cooling of Buildings Study Conducted for Department of The Army. Vol. 2 Technical Report", General Electric Co., Space Div., Philadelphia, PA, Jun. '74.

Anon., "Solar Heating and Cooling of Bulldings, Phase 0. Feasibility and Planning Study. Vol. 1, Final Report", Gen. Elec. Co., Space Div., Philadelphia, PA, (Avail. NTIS), 1974.

Anon., "Solar Heating and Cooling of Buildings, Phase 0. Feasibllity and Planning Study. Vol. 2 Technical Report", Gen. Elec. Co., Space Div., Philadelphia, PA, (Avail. NTIS), 1974.

Anon., "Solar Heating and Cooling of Bulldings, Phase 0. Feasibility and Planning Study. Vol. 3, Book 1, Appendix A, Task1, Development of Requirements. Appendix B, Task 2 Systems Definition Final Report, Gen. Elec. Co., Space Div., Philadelphia, PA, (Avail. NTIS), 1974 
Anon., "Solar Heating and Cooling of Bulldings, Phase O. Feasibility and Planning Study. Vol. 3, Book 2, Appendix C, Task 3 Assessment of Capture Potential. Appendix D, Task 4 Social and Environmental Study. Final Report", Gen. Elec. Co., Space Div., Philadelphia, PA (Avail. NTIS), 1973.

Anon., "Solar Heating and Cooling of Buildings (Phase 0 ). Feasibility and Planning Study. Final Report, Volume 3, Book 3", Gen. Elect. Co., Missile and Space Div., Philadelphia, PA, 981p., May '74.

Anon., "Solar Heating and Cooling of Buildings, Phase 0. Vol. 1 Executive Summary", TRW Systems Group, Redondo Beach, CA, (Avail. NTIS), 1974.

Anon., "Solar Heating and Cooling of Buildings, Phase 0. Vol. 2 Final Report", TRW Systems Group, Redondo Beach, CA (Avail. NTIS), 1974.

Anon., "Solar Heating and Cooling of Buildings, Phase0. Vol. 3 Appendices", TRW Systems Group, Redondo Beach, CA, (Avail. NTIS), 1974.

Anon.," "Solar Heating and Cooling Experiment for A School in Atlanta Design Report, Jun - Sep '74", Westinghouse Elec. Corp., Baltimore, MD; Georgla Inst. of Tech., Atlanta, GA, (Avail. NTIS), 1974.

Anon., (Westinghouse Elec. Corp., Baltimore, MD), "Solar Heating and Cooling Experiment for A School in Atlanta. Design Report", 1 Dec. ' 74.

Anon., "Solar Heating and Cooling of Buildings, Phase0. Final Report. Executive Summary", Westinghouse Elect. Corp., Special Systems, Baltimore, MD, (Avail. NTIS), 1974.

Anon., "Solar Heating and Cooling of Buildings. Phase 0. Final Report, Vol. 1 Final Report, Oct. '73-May '74", Westinghouse Elect. Corp., Special Systems, Baltimore, MD, (Avail. NTIS), 1974.

Anon., "Solar Heating and Cooling of Buildings, Phase 0. Final Report. Vol. 2 Appendices A-N Final Report, Oct. '73-May '74", Westinghouse Elec. Corp., Spectal Systems, Baltimore, MD, (Ava11. NTIS), 1974.

Anon., "Solar Heating and Cooling of Buildings. Phase 0 final Report. Vol. 3 Appendices 0-Y, Final Report, Oct. '73-May '74", Westinghouse Elect. Corp., Special Systems, Baltimore, MD, (Avail. NTIS), 1974.

Anon., "Solar Heating and Cooling of Buildings: Volume 2", Nat'l. Sci. Fndn., Washington, DC, 553p., 31 May ' 74.

Anon., "Solar Heating/Cooling of Buildings. Current Building Community Projects Interim Report", Nat. Acdmy. of Sciences--Nat: Rsrch. Coun., Washington, DC, (Avail. NTIS). 
Anon.,. "Solar Heating/Cooling of Buildings. Current Building" Community Projects Interim Report", National Academy of Sciences - National Research Council, Washington, DC (Avail. NTIS).

Anon., "Solar Heating and Cooling Demonstration Act of 1973. Ninety-Third Congress, Second Session, Report No. 93-769", Committee on Science and Astronautics, Washington, DC. 43 p. (GPO).

Anon., "Solar Heating and Cooling Demonstration Act of 1974 Oversight Hearings". U.S. House of Rep. Committee on Science and Technology. (Avail. Subcomm. on Energy Res., Devel. and Demo.).

Anon., "Solar Heating and Cooling Demonstration Act. Hearing Before the Subcommittee on Energy of the Committee on Science and Astronautics". Washington, DC; Subcommittee on Energy (1974). 502 p, 1974.

Anon., "Solar Home Heating and Cooling Demonstration Act, 1974. Hearing Before the Special Subcommittee on the National Science Foundation of the Committee on Labor and Public Welfare, U.S. Senate, 93rd Congress, Second Session on 5.2650 and H.R. 11864". Committee on Labor and Public Welfare. $343 \mathrm{p}, 1974$.

Anon., "Solar-MEC: A Novel Solar Energy Augmented Heating and Cooling System". Publicity Article of Institute of Gas Technology.

Anon., "Solar Research House Shows Promising Future". Elec. Constr. and Maint.; 58:184, Feb.' '59.

Anon., "Solar Thermal Energy Utilization, 1957-74, Volumes I and II".

'Technology Application Center. 1974, vp., (TAC-ST-74-600), 1974.

Anon., "Solar Total-Energy Project". Sandia Labs., Albuquerque, NM; vp., 1974.

Anon., "Strategy for Solar Heating and Cooling In Buildings". Terrestrial Applications of Solar Technology and Research (Terrastar), Auburn University, Auburn, AL, p 159, Sep. 173.

Anon., "Systems Analys is of Solar Energy Programs. Final Report". MITRE Corporation, McLean, VA. Contract NSF-C831, 325 p., (MTR-6513), Dec. '73.

Anon., "Systems Analys is of Solar Energy Programs. Appendix. Research Tasks. Final Report". MITRE Corporation, McLean, VA. Contract NSF-C831, 150 p., (MTR-6513 (App.)), Dec. 173.

Anon., "Terrastar: Terrestrial Application of Solar Technology and Research". Auburn University, Auburn, AL. Contract NGT-01-003-044, 344 p., (NASA-CR129012), Sep. '73. 
Anon., "The Development of a Solar Residential Heating and Cooling System". NASA, MSFC, Huntsville, AL (Avail. NTIS).

Anon., "1975 International Solar Energy Cong. and Expo. Extended Abstracts ("Solar Use Now - A Resource for People")". ERDA, Washington, DC, 1975.

Ashar,"N.G.; Reti, A. R., "Engineering and Economic Study of the Use of Solar Energy Especially for Space Cooling in India and Pakistan". Mass. Institute of Technology, Cambridge, MA, 23 p., 1961.

Avezov, R. R.; Zakhidov, R. A.; Umarov, G. Ya.; Minchuk, W.I., "Experimental Investigation of the Combined Operation of a Heat Pump and Solar Device with a Radiation Heating and Cooling System". Appl. Solar Energy (USSR) (English Trans1.); 6: No. 5, 31-33 (1970), 1970.

Avezov, R. R. ; Umarov, G. Ya.; Zakhidov, R. A., "Possible Use of Natural Heat Sinks in an Air-Conditioning System". Appl. Solar Energy (USSR) (English Trans 1.); 6: No. 4, 90-93, 1970.

Avezov, R. R.; Lukomsk1l, S. M.; Shafeeva, F: A., Solar Energy Utilization for Heating and Air-Conditioning". Appl. Solar Energy (USSR) (English Trans1.); 8: No. 4, 120-127, 1972.

Avezov, R. R.; Umarov, G. Ya.; Zokhidov, R. A., "Use of Solar Energy for Heating and Cooling of Buildings in Central Asia". Appl. Solar Energy (USSR) (English Trans1.); 6: No. 2, 105-9 (1970), 1970.

Babin, V. P.; Iodanishvili, E. K., "Optimization of the Operating Conditions of a Combined Generator - Cooler Thermoelement". Applied Solar Energy, Vol. 10; No. 5-6, 1974, pp. 6-9, 1974.

Bacuer, K., "Putting the Sun to Work: A History and Directory of Currently Available Solar Energy Applications". Arizona State Fuel and Energy Office, Phoenix, Arizona (Avail. NTIS).

Bailey, J. A.; Mulligan, J. C.; Liao, C. K.; Guceri, S. I., "Research on Solar Energy Storage Subsystems Utilizing the Latent Heat of Phase Change of Paraffin Hydrocarbons for the Heating and Cooling of Buildings. Semiannual report". Department of Mechanical and Aerospace Engineering, North Carolina State University, Raleigh, NC (Avail. NTIS), 1975.

Balcomb, J. D.; Hedstrom, J. C.; Moore, S. W.; Ranken, W. A.; Springer, T. E., "Last Initiatives in Solar Energy for Heating and Cooling of Buildings". Los Alamos Scientific Lab, Los Alamos, NM. [ND], vp., (Avail NTIS).

Ballantyne, E. R., "Building Design and Solar Energy". Build. Int. (English Ed.); 6, No. 5, 471-94 (Sep.-Oct 1973), 1973.

Barber, R. E., "Design and Test of a Prototype 3-Ton Solar Heated Rankine Cycle Air-Conditioner". In 1975 Intn' 1. Solar Energy Cong. and Expo., pp. $407-408,28$ Jul 1975. 
Barber, R. E., "Solar Air-Conditioning Systems Using Rankine Power Cycles Design and Test Results of Prototype Three Ton Unit". Proceedings of 21 st Annual Technical Meeting, Institute of Environmental Sciences, Anaheim, CA, April 14-16, 1975, Vol. 1, pp. 170-179 (A75-34926 16-31), Mount Prospect, IL, Institute of Environmental Sciences, April 1975.

Baughn, J.; Jackman, A., "Solar Energy Storage Within the Absorption Cycle". ASME Winter Annual Meeting, New York, NY, Nov. 17-22, 1974, 9 p., Nov. 1974.

Baum, V. A.; Kakabaev, A.; Khandurdyev, A.; Zheravlenko, V. Y.; Grossman, E. R.; Voloshin, V. T.; Shavrin, W. S., "Pilot-Plant Heliocooling Absorption Apparatus". Kholod. Tekh.; No. 8, 9-1i (1973), 1973.

Baum, V. A.; Kakabaev, A.; Chonanov, G., "Reducing the Heat Load on Buildings in Hot Climates". Appl. Solar Energy (USSR) (English Trans 1.); 5: No. 2, 73-75 (1969), 1969.

Baum, V. A.; Kakabaev, A., "Utilizing Solar Energy and Evaporative Cooling Methods for Air-Conditioning (Survey)". Appl. Solar Energy (USSR) (English Trans 1.); 8: No. 2, 57-60, 1972.

Beattie, D. A., "Session IV Advanced Research and Solar Heating and Cooling Experiments". Solar Heating and Cooling of Buildings. Iachetta, F.A. (Ed.), pp. 127-132, Washington, DC; NSF, 1975.

Beckman, W. A.; Duffie, J. A., "Modeling of Solar Heating and Air-Conditioning. Semiannual Progress Report. I Jan - 30 June, 1973". Engineering Experimental Station, University of Wisc., Madison, WI., 20 p. (NSF-RA/N-73-088), (Avail. NTIS), 31 Juily 1973.

Beckman, W. A.; Duffie, J. A., "Progress Report: Modeling of Solar Heating and Air-Conditioning". University of Wisc., Madison, WI., vp., 1973.

Beckman, W. A.; Duffie, J. A., "Solar Heating and Cooling of Buildings". Madison, WI; University of Wisconsin (1974), 24 p., 1974.

Beekman, D. M., "The Modeling of a Rankine. Cycle Engine for Use in a Residential Solar Energy Cooling System". M.S. Thesis, University of Wisconsin, Madison, WI, 1975.

Beilin, A. Yu.; Butyrskll, W. I.; Grebenkin, A. S.; Betuganov, M. A.; Kochrarev, W. I.; Epshtein, M. G.; Yakhats, M. S.; Sokolov, O. B., "Thermoelectric Pile for Household Air Conditioning". Appl. Solar Energy (USSR) (English Transl.); 5: No. 4, 89-90, 1969.

Berg, C. I., "Discussion of a Research Program for Application of Solar Energy to Space Heating, Air-Conditioning, and Water Heating in Buildings. Committee on Science and Astronautics, U.S. House of Rep., 93rd Cong., 2nd Session, Dec. 1972". Washington, DC; Committee on Science and Astronautics, vp., 1972 . 
Berkowitz, J.:B., "Technology Assessment of Solar Heating and Cooling of Buildings". Solar Heating and Cooling of Buildings, Iachetta, F.A. (Ed.), PP. 82-86, NSF, Washington, DC, 1975.

Berks, R., "Focus on Transition: Toward the Introduction of Solar Heating and Cooling to Community Planning". MITRE Corporation, Washington, DC, 31 p., July 1974.

Bessler, W.; Shen, C.N., "Study on Parameter Variations for Solar Powered Lithium Bromide Absorption Cooling". In Energy see 10; 10th Annual Intersociety Energy Conversion and Engineering Conference, Newark, De 1., August 18-22, 1975, Record (A75-45920 23-44), New York, IEEE, Inc., 1975, pp. 178-185, August 1975.

Bever, M. B., "Solar Energy Applications". Proceedings of the Discussion Group on Solar Energy Conversion; La Jolla, CA, Vol. II, pp. 61-83, 6 July 1973.

Biancardi, F. R., "Feasibility Demonstration of a Solar Powered Turbocompressor Air-Conditioning and Heating System. Quarterly Progress Report, 15 June 15 September, 1974". United Aircraft Corporation, East Hartford, Conn. (Avail. NTIS), 1974.

Biancardi, F. R.; Meader, M. D.; Blecher, W. A.; Hall, J. B., "Design and Operation of a Solar-Powered Turbocompressor Air-Conditioning and Heating System". In Energy see 10; 10th. Annual Intersociety Energy Conversion and Engineering Conference, Newark, Del., August 18-22, 1975, Record (A75-45920 23-44); New York, IEEE, Inc., 1975, pp. 186-194, August 1975.

Bliss, R. W., Jr., "Performance of an Experimental System Using Solar Energy for Heating and Night Radiation for Cooling a Building". Proceedings of UN Conf. On New Sources of Energy, Vo1. 5, pp: 148-158, New York; UN, 1964.

Boeer, K. W., "Combined Solar Thermal and Electrical Houst System". FM International Cong. on the Sun in the Service of Mankind; UNESCO House, Paris, France, 2 July 1973.

Boer, K. W., "Conversion System of the University of Delaware Solar House". From Proceedings of the Solar Heating and Cooling for Buildings Workshop; Washington, DC (21 March 1973), 21/22 March 1973.

Boer, K. W. (ED.), "Sharing the Sun! Solar Technology in the Seventies. Volume 1". American Section of ISES, Cape Canaveràl, Florida, 1976.

Boer, K. W. (ED.), "Sharing the Sun! Solar Technology in the Seventies. Volume 3". American Section of ISES, Cape Canaveral, Florida, 1976.

Boer, K. W., "Solar Heating and Cooling of Buildings: Results and Implications of the Delaware Experiment". Energy Environment, Productivity; Holmes, J. (ED.), Washington, DC; NSF (1974), pp. 50-53, 1974. 
Boeer, K. W., "Solar One - The Delaware Solar House and Results Obtained During the First Year of Operation". In Photovoltaic Power Generation; Proceedings of the International Conference, Hamburg, West Germany, Sep. 25-27, 174 (A75-2421309-20) Cologne, West Germany. Deutsche Gesellschaft Fuer LuftUnd Raumfawrt, 1974, pp 627-638; Sep.' 74.

Boeer, K. W.; Higgins, J. H.; O'Connor, J. K., "Solar One, Two Years Experience - Prototype Home Thermal and Electric System". In Energy 10; 10th Annual Intersociety Energy Conversion and Engineering Conference, Newark, Del., Aug. 18-22, 75 Record. (A75-45920 23-44) New York, IEEE, Inc., 1975, pp 7-13; Aug '75.

Böer, K. W., "The Solar House and its Portent". Chemtech, pp 394-400; Jul 173.

Bonauguri, E., "Solar Absorption Unit". Progr. Refrig. Sci. Tech.; 2:1411$1422 ; 1969$.

Bourke, R. D.; Davis, E. S., "Solar Heating and Cooling of Buildings". In Energy Delta Supply Vs. Demand; Proceedings of the Energy Symposium, San Francisco, CA, Feb. 25-27, 174. (A75-27776 11-44) Tarzana, CA, AAS, 1975, pp 327-357; Feb '74.

Brandvold, G. E., "Solar Total - Energy Community Project". Sandia Labs., Albuquerque, NM (Contract AT(29-1) -789, 9p; Mar 174.

Braun, G. W.; Davis, E. S.; French, R. L.; Hirschberg, A. S.; "Assessment of Solar Heating and Cooling for an Electric Utility Company". In 1974 Intn' 1. Solar Energy Cong. and Expo., pp 37-38. Rockville, MD; ISES; 1975.

Bridgers, F. H., "Applying Solar Energy for Cooling and Heating Institutional Buildings". In Solar Energy Applications; pp 17-25. ASHRAE; New York. Also ASHRAE TRANS.; 80: No. 2, 365-373; 1974.

Bryson, F. E., "Plugging in the Sun". Machine Design; 46: No. 3, pp 20-25: 7 Féb 74.

Bruechert, C. J., "Solar Energy and the Mechanical Contractor". ASHRAE J.; pp 66-67; Nov 75 .

Buchberg, H.; et al., "Natural Convection in Enclosed Spaces - A Review of Applications to Solar Energy Collection". AIAA TI5 $3 / 44$.

Buckley, S., "Thermic Controls of Regulate Solar Heat Flux Into Buildings. Semiannual Progress Report, 1 Jan. - 30 Jan. '75". Dept. of Mech. Eng'ng., MIT, Cambridge, MA. (Avail NTI5); 1975.

Bunas, S. J., "EPA-VAN: A Clean Energy System for the Home". Tenth Intersociety Conversion Engineering Conference, pp 241-245. New York; IEEE (1975); 17 Aug ' 75. 
Burke, J. C., "Massachusetts Audubon Society Solar Building". From Proceedings of the Solar. Heating and Cooling for Buildings Workshop, Wash., DC, Mar 21-23, '73, Part 1: Technical' Sessions; 21 Mar 73.

Butler, T. W., Jr., "Wind and Solar Energy Conversion System for Multi-Story Buildings": U.'S. Patent 3,832,853. 3 Sep '74. Filed 26 Mar 173, 8 pp; 1974.

Butt, S., "Solar Energy Industry and the Design Professions". Prof. Eng.; 45: No. 8, pp 23-25; Aug' 75.

Butt, T. K.; Sartor, D. A., "Total Systems Economic Analysis: A Marketing Strategy for Solar Energy Applications". In 1975 Intn'l. Solar Energy Cong. and Expo., pp 35-36. Rockville, MD; ISES; 1975.

Butz, L. W.; Beckman, W. A.; Duffie, J. A., "Simulation of a Solar Heating and Cooling System". Solar Energy; 16: pp 129-138; 1973.

Butz, L. W.; Beckman, W. A.; Duffie, J. A., "Simulation of a Solar Heating and Cooling System-for Houses". Solar Energy, Vol. 16, Dec 14, pp 129-136; Dec 174. 
Chapman, H. L., "Rock Pile Thermal Storage Heating and Cooling System". Commonwealth Scientific and Industrial Research Organization; Victoria, Australia (1970). 7 pp; 1970.

Cherry, W. R., "Conclusions and Recommendations of the Solar Energy Panel". ASME. 12 pp; 1972.

Cherry, W. R., "Harnessing Solar Energy: The Potential". Astronautics and Aeronautics; 11: 8, pp 30-36; Aug 173.

Cherry, W. R., "Solar Energy Research and Utilization". NASA, GSFC, Greenbelt, MD. 23 pp. (NASA-TM-X-70660; X-704-74-139); May '74.

Cherry, W. R., "Some Major Terrestrial Applications of Solar Energy". IEEE Intercon Tech Paper 1973, Vol. 3, Paper 6/3, 8 pp.; 1973.

Chinnappa, J. C. V., "Computed Year-Round Ferformance of Solar=operatad MultiStäge Vapour Absorption Air Conditioners at Georgetown, Guyana and Colombo, Ceylon". From Intn'1. Cong. on the Sun in the Service of Mankind, UNESCO House, Paris, France; 2 Jul ' 73.

Chinnappa, J. C. V.; Martin, H. A., "Dual-Mode Operation of an Ammonia-Water. Multi-Stage Cycle: A Comparative Study". In 1975 Intn'l Solar Energy Cong. and Expo. pp 398-399; 28 Jul 175.

Chinnappa, J. C. V., "Solar Operation of Ammonia-Water Multi-Stage Air Conditioning Cycles in the Tropics". In Solar Energy, Vol. 16, No. 3/4, Dec "74, pp 165-170; Dec ' 74 .

Chung, R.; Duffie, J. A.; Löf, G. 0. G., "A Study of a Solar Air Conditioner". Mechanical Engineering; 85:31; 1963.

Chung, R.; Duffie, J. A., "Cooling with Solar Energy". Proceedings of UN Cong. on New Sources of Energy. Vol. 6, pp 20-30. New York; UN; 1964.

Chung, R.; Löf, G. O. G.; Duffie, J. A., "Experimental Study of LIBR-H 0 Absorption Air Conditioner for Solar Operation. ASME Paper 62-WA-347". ASME Mech.

Eng.; 85; No. 8, 31-5; Aug '53.

Chung, R.; Löf, G. O. G.; Duffie, J. A., "Solar Space Cooling". Chemical Eng. Prog.; 55: No. 4, pp 74-78; Apr 59.

Clementson, S. P., "Air Conditioning Data". Heating and Ventilation Engrg.; 38: No. 450, 365-8; Jan ' 65.

Close, D., "Design and Performance of a Thermal Storage Air Conditioning System". J. Inst. Engineers, Aust.; MC-4: No. 1; 1968.

Close, D. J.; Dunkle, R. V.; Robeson, K. A., "Design and Performance of Thermal Storage Air Conditioning System". Mechanical Chemical Engineering Trans,; MC4: No. 1, pp 45-54; May '68. 
Cohen, A. D., "Acceptability and Implementation of SHACOB Systems: A Report by General Electric Company". - Solar Heating and Cooling of Bufldings, Iachetta, F. A. (Ed.), Washington, DC; pp 109-116. NSF; 1975.

Cohen, A.; Phase 0 . Feasibility and Planning Study: A Report by General Électric Company". Solar Heating and Cooling of Buildings, pp 4-21. Iachetta, F. A. (Ed.) Washington, DC; NSF; 1975.

Comstock, W. S:; "Sölar Energy Today and Tomorrow". ASHRAE J.; p 75; Nov "75.

Coonley, D.; Anderson; B., "An Ecological Solar Heated and Cooled Home": In 1975.Intn'1. Solar Energy Congress and Expo., pp 77-78. Rockville, MD; ISES; 1975.

Costello, F. A., "A Hybrid Solar Air Conditioning System". In Solar Energy; 18: No. 2, pp 149-152; 1976.

Cottingham, J. G.; Green, G. K., "Solar Powered Steam Supplement for Heating and Cooling of Buildings". Brookhaven Nat'l Lab, Upton, NY 9 p. (CONF-741141 $-2)$. In Proceedings of the Workshop on Solar Collectors for Heating and Cooling of Buildings, pp 158-162.

Couch, W. A.; San Martin, R. L., "Continuous Absorption Air Conditioning Utilizing Solar Energy". In 1975 Intn'l Solar Energy Congress \& Expo. Pp $392-393 ; 28 \mathrm{Ju} 1 \mathrm{l} 75$.

Couch, J. P.; Bloomfield, H. S., "The NASA-Lewis/ERDA Solar Heating and Cooling Technology Program".. ISES and ASHRAE Workshop on the Use of Solar Energy for the Cooling of Buildings, Los Angeles, CA, Aug. 4-6, '75. Paper, 14 pp; Aug 75.

Courtney, R. C.; Hogg, F. G.; et al., "Solar Energy Around the Worid". ASHRAE J.; pp 72-73; Nov' 75.

Crall, G. C.; Jones, C. D.; Sepsy, C. F.; Jones, J. W., "A Computer Simulation and Validation of a Building Heating, Ventilation and Air Conditioning System". ASHRAE Paper No. 2361 RP-66-05. 13 pp; [ND].

Crausse, E.; Gachon, H., "Study of a Saharan Solar House". Proceedings of UN Conf. on New Sources of Energy". Vo1. 6, pp 81-86. New York; UN; 1964.

Crowther, R. L., "Solar Energy: The Architectural Imperative". ASHRAE J.; pp 63-65; Nov' 75.

Curran, H. M.; Lokmanhekin, M.; Alereza, T.; Miller, M., "Assessment of Rankine Cycle for Potential Application to Solar-Powered Cooling of Buildings". ASME Winter Annual Meeting, New York, NY, Nov 17-22, 174. 15 p; Nov 14.

Curran, H.M.; Lokmanhekim, M.; Alereza, T., "Assessment of the Ranking Cycle for Potential Application of Solar Powered Cooling of Buildings. Final Report". Hittman Associates, Inc., Columbia, MD (Avail. NTIS). Contract C-858. 145p. (NSF/RA/N-74-108); Aug 174. 
Curran, H. M. , "Assessment of Solar-Powered Cooling of Bulldings - Energy Policy Final Report". Hittman Assoc., Inc., Columbia, MD (Avail. NTIS); Apr 175.

Curran, H. M., "Coefficient of Performance for Solar-Powered Space Cooling Systems". In ". Sharing the Sun! Solar Technology in the Seventies Vol 3"; Böer, K. W. (Ed.). pp 90-98; 1976.

Curran, H. M.; Miller, M., "Evaluation of Solar-Assisted Rankine Cycle Concept for the Cooling of Buildings". In Energy 10; 10th Annual Intersociety Energy Conversion and Engineering Conference, Newark, Del., Aug 18-22, 175. Record. (A75-45920 23-44) New York, IEEE, Inc. 1975, pp 1391-1398; Aug 75. 
Danby, M., "Design of Buildings in Hot-Dry Climates and the Internal Environment". Build. Int. (Engl. Ed.); 6:1, pp 55-76 (Jan-Feb 1973); 1973.

Daniels, F., "Solar Energy". Electr. Eng. (Sidney); 74:11, pp 959-951; Nov '55.

Dannies, J. H., "Solar Air Conditioning and Solar Refrigeration". Solar Energy; $3: 1$, pp 34-39; Jan '59.

Dannies, J. H., "Thermodynamic Treatment of Air by Solar Radiation". Solar Energy; 3:1, pp 23-28; Jan '59.

Dao, K.; et al., "Performance of an Air-Cooled Ammonia-Water Absorption Air Conditioner at Low Generator Temperatures". In "Sharing the Sun! Solar Technology In the Seventies. Vol 3"; Böer, K. W. (Ed.), pp 46-52; 1976.

Davis, C. P., Jr.; Mowry, G. R., "Solar Supplemented Heat Pump for Rural Home Air Conditioning". Paper No. 60-822. Lafayette, IN; Purdue Univ. 30 p.; Dec '60.

Davis, E. S.; Wen, L. C.; French, R. L., "New Cost-Saving Method for Calculating the Long-Term Performance of Solar Heating and Cooling Systems". In 1975 Intn' 1. Solar Energy Congress \& Expo. from Annual Meeting of ISES. Los Angeles, CA, pp 291-292; 28 Jul 175.

Davis, C. P., Jr.; Lipper, R. I., "Sun Energy Assistance for Air-Type Heat Pumps". Heat. Piping Air Cond.; 29:12, pp 123-128; Dec '57.

Dean, T., "Solar Assisted Heat Pump Air Conditioning System". In "Sharing the Sun! Solar Technology in the Seventies. Vol. 3"; Böer, K. W. (Ed.) pp 373-377; 1976.

Denton, J. C., "Integrated Solar-Powered Climate-Conditioning Systems. SemiAnnual Progress Report Covering the Period Jan. I through Jun. 30, 1975". Nat'l Center for Energy Management and Power, Penn. Univ., Philadelphia, PA. 70 pp; 31 JuT 174.

Desa, V. G., "Solar Radiation in Air-Conditioning and Flat Flate Collectors". J. Inst. Engr. (Pakistan); 5:21-33 (1958); 1958.

Dewinter, F., "Workshop Proceedings on Solar Cooling for Buildings, Held in Conjunction with the Semi-Annual Meeting of the ASHRAE". Cal. Inst. of Tech., Pasadena, CA. (Avail NTIS); 1974.

Diamond, S.; et al., "A Solar Heated and Cooled Office Building". In "Sharing the Sun! Solar Technology in the Seventies. Vol. 3"; Böer, K. W. (Ed.). pp 99$105 ; 1976$.

Dikkers, R. D., "Development and Implementation of Standards for Solar Heating and Cooling Applications". In "Sharing the Sun! Solar Technology in the

Seventies". Vo1. 1; Böer, K. W. (Ed.). pp 83-90; 1976. 
Donk, R. L.; Beckman, W. A.; Duffie, J. A.; "Modeling of the CSU.Heating/Cooling System". In 1975 Intn'1. Solar Energy Congress \& Expo. pp 295-296; 28 Jul '75.

Donovan, P.; Woodward, W.; Cherry, W. E.; Morse, F. H. ; Herwig, L. 0., "Assessment of solar Energy as a National Resource". Dept. of Mech. Engineering,

Maryland Univ., College Park, MD. 89 pp. (Avail NTIS); Dec 172.

Donovan, P.; Herwig, L. 0.; et al., "International Solar Energy Society U. S. Section Annual Meeting". NASA-LRC, Cleveland,OH. 95 pp; Oct 3-4, '73.

Drumheller, K., "Solar Energy Technology". Battelle Pacific Northwest Labs, Richland, WA. 34 pp; 22 Mar' 75.

Dubin, F. S., "GSA's Energy Conservation Test Building: Report". Actual Specif. Eng.; 30:2, pp 84-92; Aug '73.

Dubin, F. S.; "Solar Energy Design for Existing Buildings". ASHRAE J.,; pp 53-55; Nov '75.

Dudlely, J. C., "Thermal Energy Storage Unit for Air Conditioning Systems Using Phase Change Material". National Center for Energy Management and Power, Philadelphia, PA (Avail. NTIS).

Duffie, J. A.; Beckman, W. A., "A Review of Solar Cooling". In "Sharing the Sun! Solar Technology in the Seventies. Vol 3"; Böer, K. W. (Ed.). pp 13-26; 1976.

Duffie, J. A.; Sheridan, N. R., "Lithium Bromide-Water Refrigerators for Solar Operation". Chem. Engr. Trans., Inst. Engrs.; Australia, MC-1, 79; 1965.

Duffie, J., "Modeling of Solar Heating and Air Conditioning". Proceedings of the Solar Heating and Cooling for Buildings Workshop. Part I: Technical Sessions, pp 149-152; Washington, DC; Mar 173.

Duffie, J. A.; Beckman, W. A., "Modeling of Solar Heating and Air Conditioning Semi-Annual Progress Report Covering the Period Feb. 1 to Oct. 31, '74". Engineering Exp. Sta., Wisconsin Univ., Madison, Wis. 80 pp; 31 0ct 74.

Duffie, J. A.; Beckman, W. A., "Modeling of Solar Heating and Air Conditioning". Madison, WI; Univ. of Wisconsin. vp; 1973.

Duffie. J. A.; Lof, G. 0. G., "Solar Energy: Economics and Engineering Research at the University of Wisconsin". Can. J. Chem. Eng., pp 77-34; Apr '59.

Duffie, J. A.; Beckman, W. A., "Solar Energy Thermal Processes". John Wiley and Sons; New York (1974). 386 pp.

Duffie, J. A.; Beckman, W. A., "Solar Heating and Cooling". Science, Vol. 191, Jan. 16, '76, pp 143-149; Jan 176.

Duffie, J. A.; Chung, R.; Lof, G. 0. G., "Study of a Solar Air Conditioner". Mech. Eng.; 85:8, 4 pp (Aug '63); Aug '63. 
Duffie, J. A.; Lof, G. 0. G., "University of Wisconsin Research Program". Solar Energy; 3:3, pp 16-18; Jul' 59 .

Duncan, R. T., "Solar Energy will Cool and Heat Atlanta School". ASHRAE J; 16:9, pp 47-49; Sep ' 74 .

Dunkle, R. V., "Method of Solar Air Conditioning". Inst. Engrs., Australia, Mech. and Chem. Eng. Trans.; MCI:No. 1, pp 73-78; May '65.

Dunkle, R. V., "Potential Applications of Spectrally Selective Materials in Air Conditioning". Symposium on Air-Conditioning-An Aid to Tropical Living". Unk.; ANZAAS. 13 pp; 1961. 
Eoenburn, M. V., "Building 832 and Small-Neighborhood Applications for Sandia Laboratories Solar Energy System Test Bed". Sandia Labs, Albuquerque, NM. Contract AT (29-1)-789. 26 Pp (Avail NTIS); JuI 175.

Eggers, A. J., Jr., "Solar Energy: Status and Prospects as a National. Resource". ASHRAE, J.; PP 41-43; Nov 175.

Eibling, J. A.; Frieling, D. H., "A Solar Heat Pump". Solar Energy, Vol. 17, Nov. '75, pp 313-315; Nov '75.

Eibling, J. A., "Future Possibilities for the Use of Solar Energy in Buildings". Proceedings of the Conf. on Energy Conservation in Commercial, Residential, and Industrial Buildings, Ohio State Univ., Columbus, OH, May 5-7, 174, PP 305-308; 1974.

Eibling, J. A., "Study of Energy Storage". Proceedings of the Solar Heating and Cooling for Buildings Workshop. Part I: Technical Sessions, pp 69-72. Washington, DC; Mar 173.

Eisenstadt, M.,; Flanigan, F. M.; Farber, E. A., "Solar Air Conditioning with an Ammonia-Water Absorption Refrigeration System". ASME-59-A-276. 8 pp. From Annual Meeting of ASME; Atlantic City, NJ (29 Nov - 4 Dec '59); 1959.

Eisenstadt, M.; Flanigan, F. M.; Farber, E. A., "Tests Prove Feasibility of Solar Air Conditioning". Heat., Piping Air Cond., pp 120-126; Nov '60.

Ezra, A. A., "Technology Utflization - Incentives and Solar Energy". Science, Vo1. 187, Feb 28, 175. pp 707-713; Feb 175. 
Fairbanks D. R. "A Computer Program to Determine the Optimum Configuration of Solar Assisted Building Heating and Cooling Systems Based Upon Life-Cycle Cost". In Energy 10; 10th Annual Intersociety Energy Conversion and Engineering Conference, Newark, Del., Aug 18-22, '75. Record. (A75-45920 23-44).

New York. IEEE, Inc., 1975, pp 202-209; Aug '75.

Fan, J. C. C.; Bachner, F. J., "Transparent Heat Mirrors for Solar-Energy Applications". Applied Optics; 15:4, pp 1012-1017; Apr '76.

Farber, E. A.; Morrison, C. A., "A Case Study-Utilization of Solar Energy in Residential Dwellings". ASME Winter Annual Meeting, New York, NY, Nov 17-22, '74, 8 pp; Nov' 74.

Farber, E. A., "Direct. Use of Solar Energy to Operate Refrigeration and Air Conditioning Systems". Fla. Eng. Indus. Exp. Station; 14:11, vp; Nov '65.

Farber, E., "Florida Program in Solar Refrigeration and Air Conditioning". Solar Energy; 3:3, pp 33-34; Jul '59.

Farber, E. A.; Morrison, C. A.; Ingley, H. A., "Formulation of a Data Base for the Analysis, Evaluation and Selection of a Low Temperature Solar Powered Air Conditioning System". Dept. of Mech. Eng., Florida Univ., Gainesville, Fla; 31 Jul' 74.

Farber, E. A.; Flanigan, F. M.; Lopez, L.; Polifka, R. W., "Operation and Performance of the University of Florida Solar Air-Conditioning System". Solar Energy; 10:2, pp 91-95; Apr-Jun '66.

Farber, E. A.; Morrison, C. A.; Ingley, H. A., "Selection and Evaluation of the University of Florida's Solar Powered Absorption Air Conditioning System". ASME Winter Annual Meeting, New York, NY, Nov 17-22, '74. 10 pp; Nov ' 74.

Farber, E. A.; Morrison, C. A.; Ingley, H. A.; Clark, J. A.; Suarez, E., "Solar Operation of Ammonia/Water Air Conditioner". In 1975 Intn'1. Solar Energy Congress \& Expo. pp 402-402; 28 Jul ' 75.

Farber, E. A.; Morrison, C. A.; Ingley, H. A.; Suarez, E., "The University of Florida Solar Powered Intermittent Ammonia/Water Absorption Air Conditioner.". Proceedings of 21 st Annual Technical Meeting, Institute of Environmental Sciences, Anaheim, CA, April 14-16, 175. Vol. 1, pp 202-205 (A75-34926 16-31) Mount Prospect, IL, Inst. of Env. Sciences; April 175.

Farber, E. A., "University of Florida Solar Energy Laboratory". From Intn'] Congress on the Sun in the Service of Mankind; UNESCO House, Paris, France; 2 Jul 173.

Farnham, L. L.; Stewart, J. K.; Petron, N. V., "Solar Heating and Cooling of Buildings: Problems of Commercialization". Energy, Environment, Productivity. Holmes, J. (Ed.). Washington, DC; NSF (1974), pp 54-59; 1974. 
Fenner, W. E., "Solar Energy Caps. Unique System". Heating, Piping Air Cond., 47:7, pp 41-43; Jul '75.

Field̄s, R. H., "Solar Demonstration Activities". Energy Technology II. pp 176-179. Sullivan, T. F. P. (Ed.). Washington, DC. Government Institutes, Inc.; 1975.

Fischer, R. D.; Frieling, D. H.; Talbert, S. G.; Eibling, J. A., "Solar-Powered Heat Pump with Pivoting-Tip Vane Expander and Compressor". In 1975 Intn' 1 Solar Energy Congress \& Expo. pp 419-420; 28 Jul ' 75.

Freeman, T. L., "Computer Modeling of Heat Pumps and the Simulation of Solar Energy-Heat Pump Systems". M. S. Thesis, University of Wisconsin, Madison, WI; 1975.

Freeman, T. L.; Beckman, W. A.; Mitche11, J. W.; Duffie, J. A.; "Computer Modeling of Heat Pumps and the Simulation of Solar-Heat Pump Systems".

ASME Winter Annual Meeting, Houston, Tex., Nov 30-Dec 4, '75. 16 pp; 1975.

Frieling, D. H.; Fischer, R. D.; Yano, R. A.; Eibling, J. A., "Advanced Research Implications of the Phase 1 Program Results on Solar Heating and Cooling of Buildings". In 1975 Intn'1 Solar Energy Congress and Expo., pp 22. Rockville, MD; ISES; 1975.

Frieling, D. H.; Fischer, R. D.; Yano, R. A.; Eibling, J. A., "Critical Review and Analysis of the Advanced Research Implications of the Phase $\varnothing$ Program Results on Solar Heating and Cooling of Buildings". Battelle Columbus Labs, OH. 31 Mar 175. 104 pp; Mar 175. 
Gardner, E.; Woisard, E., "Thermoelectric Materials for Space Cooling".

Conf. Paper; ARS Space Power Systems Conf., Santa Monica, CA. 7 pp; Sep 1960.

Gilman, S. F.; "Evaluation of the Solar Building, Albuquerque, New Mexico. Annual Technical Progress Report," Covering the Period April 1, 1974 -December 31, 1974. 47 pp.; 31 Jan 1975.

Gilman, S. F.; Sturz, D. H., "Solar Energy Assisted Heat Pump Systems for Commercial Office Buildings". In Solar Energy Applications, pp 25-33. ASHRAE, Inc., New York, also ASHRAE Trans; Vol. 80: No. 2, pp 374-381; 1974.

Gilman, S., "Solar Energy Assisted Heating Systems for Commercial Buildings". Proceedings of the Conf. on Energy Conservation in Commercial, Residential, and Industrial Buildings; Ohio State Univ., Columbus, $\mathrm{OH}$; $10 \mathrm{pp}$; May 5-7, 1974. May 1974.

Gilman,.S. F., "Solar Energy Heat Pump Systems for Heating and Cooling Buildings". ERDA DOC. COO-2560-1; 1976.

Givoni, B., "Utilization of Natural Energies for Heating and Cooling of Houses". Guild. Int. (Engl.Ep); 7: No. 2, pp 179-188; Mar-Apr 1974.

Glaser,.P. E., "Energy Conservation with Solar Climate Control: Solar Heating and Cooling of Buildings". Arthur D. Little, Inc., Cambridge, MA. 9 pp; 14 Nov 1973.

Glaser, P. E., "Energy Conservation with Solar Climate Control". Proceedings of Building for Energy Conservation, pp 90-95; Amherst, MA (1975); 11 Dec. 1973.

Glaser, P. E., "New Sources of Power: Solar Energy". World Energy Supplies Conf., London, Eng. 13 pp; Sept 18-20, 1973; Sep 1973.

Glaser, P. E. "Potential of Solar Energy Applications". AICHE Symposium, Series 125, pp 55-65; 1972.

Glaser, P. E., "Solar Climate Control: An Emerging New Business". Prof. Eng.; 45: No. 8, 28-31 (Aug. 1975); Aug 1975.

Glaser, P. E. "Tomorrow Solar Energy". Ind. At Spat.; 18: No. 1, pp 26-30; 1974.

Glickman, L. R., "Solar Energy Dehumidification Experiment". Reports to NSF Under Grant No. PTP 75-005156; 1975.

Goen, R. L., "Assessment of Total Energy Systems for the Department of Defense". Vol. 1; Final Report; Stanford Research Inst., Menlo Park, CA. Contract DACA23-73-C-0014. 122 pp (SRI-EGU-2513 (Vo1. i)); Nov 1973. 
Goen, R. L.; Stout, G.; Beaulaurier, L. P.; Schmidt, R. A.; Ryan, J. W., "Assessment of Total Energy Systems for the Department of Defense". Vol. 2.; Appendices, Final Report; Contract DACA23-73-C-0014; 160 pp (SRI-EGU-2513 (Vol. 2)); Nov 1973.

Grassie, S. L.; Sheridan, N. R., "Modeling of a Solar-Operated Absorption Air Conditioner System with Refrigerant Storage". "Sharing the Sun! Solar Technology in the Seventies. Vol. 3" Boer, K. W. (Ed.); pp 53-67; 1976.

Graven, R. M., "Comparison of Computer Programs Used for Modeling Solar Heating and Air Conditioning Systems for Buildings". Lawrence Berkley Lab., California Univ., Berkley, CA. (Avail NTIS); 1974.

Grey, J., "Solar Heating and Cooling". Astronaut.Aeronaut.; 13: No. 11; pp 33-37; Nov 1975.

Grossman, G. R.; Roberts, A. S. Jr., "Investigation of Current University Research Concerning Energy Conversion and Conservation in Small Single-Family Dwellings". Final Technical Report; 7 Apr = 7 Aug 1975; 01d Dürinion Urifv., School of Eng., Norfolk, Va. (Avail. NTIS); 1975.

Gupta, C. L., "Thermal Design Model for a Natural Air-Conditioning System with Application to Poultry Sheds in Hot Arid Regions". In 1975 International Solar Energy Cong. and Expo., pp 51-52, ISES, Rockville, MD; 1975. 
Haggard, K. L., "Archecture of a Passive System of Diurnal Heating and Cooling". In 1975 International Solar Energy Cong. and Expo.; pp 443-444; 28 Jul 1975.

Haines, R., "Solar Collector and Heat Pump Heats, Cools New Office Buildings". Heat., Piping Air Cond.; 28: No. 10, pp 104-107; Oct 1956.

Hancock, 0. G., Jr.; Harrenstein, H. P.; Lowery, G. W., "Solar Cooling of a Florida Welcome Station, A Demonstration". In "Sharing the Sun! Solar Technology in the Seventies. Vol. 3"; Boer, K. W. (Ed.); pp 190-199; 1976.

Harrigan, R. W. (Ed), "Solar Total Energy Program Semiannual Report". Progress Report, Oct. 74 - Mar 75. Sandia Labs., Albuquerque, New Mexico Contract AT (29-1)-789. $80 \mathrm{pp;} \mathrm{Jul} 1975$.

Hay, H. R., "Califormia Solarchitecture House". International Congress on the Sun in the Service of Mankind; UNESCO House, Paris, France; Pp EH.73.1-EH.73.10; 2 Jul 1973.

Hay, H. R.; Yellott, J. I., "Construction and Operation of Naturally AirConditioned Building". ASME Paper 68-WA/SOL-2. New York; ASME. 12 pp; 1968.

Hay", $H_{:}$, "Development of Natural Air Conditioning". Arch. Concept; 28: No. $313, ; 4$ pp ; 1973.

Hay, H. R., "Energy, Technology, and Solarchitecture". ASME, Winter Annual Meeting; 7 pp; 1972.

Hay, H. R., "Energy, Technology, and Solarchitecture". Mech. Engr.; 95: No 11; pp 18-22; Nov 1973.

Hay, H. R.; Hellott, J. I., "International Aspects of Air Conditioning with Movable Insulation". Sol. Energy; 12: pp 427-438; 1969.

Hay, H. R.; Yellott, J. 1., "Natural Air Conditioning with Roof Ponds and Movable Insulation". Trans. ASHRAE; 75: pp 165-177; 1969.

Hay, H. R.; Yellott, J. I., "Naturally Air-Conditioned Building". ASME, Winter Annual Meeting; 12 pp; 1968.

Hay, H. R.; Yellott, J. I., "Naturally Air-Conditioned Building". Mech. Eng; 92: No. 1; pp 19-25; Jan 19670.

Hay, H., "New Roofs for Hot Dry Regions". EKISTICE; No. 183, 158 (1971); 1971.

Hay, H. R., "Passive Thermal Control Systems: Philosophy and Reality". In 1975 International Solar Energy Cong. and Expo., pp 48-49; Rockville, MD; ISES; 1975.

Hay, H. R., "Roof-, Ceiling-, and Thermal-Ponds". In 1975 International Solar Energy Cong. and Expo.; Rockville, MD; ISES. pp 335-336; 1975. 
Hay, H. R.; Yellott, J. I., "Thermal Analysis of Buildings with Natural Air Conditioning". Trans. ASHRAE; 75: pp 178-190; 1969.

Hedstrom, J. C.; Balcomb, J. D.; Meckler, G., "Comparative Analysis of LIBR Absorption, Dehumidification and Solar-Rankine cooling System Options for a $66,000 \mathrm{Ft}^{2}$ Building in Los Alamos, New Mexico". Los Alamos Scientific Lab., Los Alamos, NM. 26 pp (CONF-740811-2). (Avail. NTIS); 1974.

Herwig, L. 0., "Summary of the Role of Planning and Analys is in the Development of the Federal Solar Energy Program". In "Sharing the Sun! Solar Technology in the Seventies. Vol. 1"; Boer, K. W. (Ed); pp 189-210; 1976.

Hessel - Schwerdt; A. L., Jr., "Converting Solar Energy Intu Confort". Refrig. Eng.; 62: No. 8, 55, 94; Aug 1954.

Hildebrandt, A. F., "Potential of Solar Energy for Texas". Final Report; Texas Governor's Energy Advisory Council, Austin, TX (Avail NTIS); 1974.

HIII, J. E.; Richtmyer, T. E., "Design and Operation of a Retrofitted Resiential Solar Heating and Cooling System". In 1975 International Solar Energy Cong. and Expo.; pp 324-325; 28 JuT 1975.

Hill, J. E., "Laboratory Based Activities in Solar Energy at the National Bureau of Standards". ASTM Standardization News, Vol. 3, pp 20, 21, 24-28; Aug 1975.

Hill, J. E.; Richtmyer, T. E., "Retrofitting a Residence for Solar Heating and Cooling: The Design and Construction of the System". Center for Butlding Technology, National Bureau of Standards, Washington, DC (Avail NTIS)

Hill, R. F. (Ed), "Energy Technology III - Commercialization". Proccedings of the 3rd Energy Tech. Conf., Government Institutes, Inc. (Pub); Washington, DC 335 pp; 1976.

Hirshbert, A., "Policy Issues for the Rapid Implementation of Solar Energy". In 1975 International Solar Energy Cong. and Expo. Rockville, MD; ISES. $p$ 19; 1975.

Hittle, D. C.; Walton, G. N.; Holshouser, Dr. D. F., "Method for Estimating Solar Heating and Cooling System Performance". Paper presented at 1975 meeting of ISES. $19 \mathrm{pp} ; 1975$.

Holland, T. H., "Transportable Solar Laboratory Test Results and Utilization Study for Albuquerque, N. M." Systems and Research Center, Honeywell, Inc., Minneapolis, Minn. 20 pp; (AVAIL NTIS); Jan 1975.

Holland, T. H., "Transportable Solar Laboratory Test Results and Utilization Study for Dallas, Texas". Systems and Research Center, Honeywell, Inc., Minneapolos, Minn. 41 pp. (avail. NTIS); Apr 1975. 
Holland; T. H., "Transportable Solar Laboratory Test Results and Utilization Study for Miami, Florida". Systems and Research Center, Honeywell, Inc., Minneapolis, Minn. 50 pp (Avail. NTIS); Apr 1975.

Hollands, K. G. T., "Regeneration of Lithium Chloride Brine in a Solar Still for Use in Solar Air Conditioning". Solar Energy; 7: No. 2, pp 39-43 (Apr June 1963); 1963.

Holshausen, C., "Sun Penetration and Exclusion in Tropical Regions". Sunlight in Buildings, Proceedings of the CIE Intersessional Conf., Newcastle-UponTyne, Eng., 1965: p 351; 1965.

Anon, "Design and Test Report for Transportable Solar Laboratory Program". Honeywe 11, Inc.; Oct 1974.

Anon., "Solar Energy Collectors for Heating and Cooling". Systems and Research Center, Honeywe11, Inc, Minneapolis, MN. 53 pp. Aug 1974.

Horigome, T.; et al, "Solar Energy". Scientific Translation Service. December 1974.

Horowitz, H., "Heating and Cooling of Buildings with Solar Energy". ASHRAE Trans.; 80: No. 2, pp 393-400. Also in Solar Energy Applications; $Y$

Yellott, J. I. (Chairman). ASHRAE, Incl, New York. pp 45-52; 1974.

Horowitz, H., "National Science Foundation's Advanced Research Program on Heating and Cooling of Buildings with Solar Energy". ASHRAE Trans.; 80, Part II: 1974.

Hottel, H. C., "Residential Uses of Solar Energy". Proceedings of the. World Symposium on Applied Solar Energy; pp 103-112. Menlo Park, CA; Stanford Research Institute; 1956.

Hughes, P. J.; Klein, S. A.; Close, D. J., "Packed Bed Thermal Storage Models for Solar Air Heating and Cooling Systems". Journal of Heat Transfer, Transactions of the ASME; 3 pp; May 1976.

Humphries, W. R.; Melton, D. E., "Solar Residential Heating and Cooling System Development Test Program". NASA, MSFC, Huntsville, AL (Avail NTIS) 129 pp.

Hundemann, A. S., "Solar Heating and Air Conditioning. (A Bibliography with Abstracts)". Period Covered: 1964 - Dec. 1974. NTIS, Springfield, Va.; Feb. 1975. 76 pp; Feb 1975.

Hundemann, A. S., "Solar Heating and Air Conditioning. (A Bibliography with Abstracts)". Report for 1964-Aug 1975. NTIS, Springfield, Va. 128 pp. Sep 1975. 
Iachetta, F. A. (Ed), "Proceedings of the Workshop on Solar Heating and Cooling of Bulldings", Washington, DC; June 17-19, 1974. Washington, DC; NSF. 164 pp. (NSF-RA/N-74-126; Conf -7406105-); 1975.

Ingley, H. A., "Design and Development of a Solar Powered Anmonia/Water Air Conditioning System". Build. Syst. Des.; 72: No. 4, pp 14-16; (1975).

Irby, J. E.; Nash, J. M., "Unified Simulation Capability for Solar Heating and Cooling System Analysis". IBM Hsv Report No. 76TPA0011. 16 Pp; 1976.

Ishibashi, T., "Result of Cooling Operation of Yazaki Experimental Solar House One". In 1975 International Solar Energy Cong. and Expo. pp 340-341; 28 Jul 1975. 
Jacobsen, W. E.; Bisselle, C. A., "Solar-Thermal Energy Program". The Mitre Corp., Washington, DC 159 pp; July 1974.

Jagadish, S. R., "Prospects of Uttlization of Solar Energy and Wind Power for Generation of Power, Air Conditioning and Refrigeration in the Climatic Condition Similar to India". From International Congress on the Sun in the Service of Mankind; UNESCO House, Paris France. 2 July 1973.

Jain, S. P.; Rao, K. R., "Experimental Study of the Effect of Roof Spray Cooling on Unconditioned and Conditioned Buildings". Build. Sci.; 9: No. 1, pp 9-16; March 1974.

Jardine, D. M., "Phoenix Project": Solar Heating and Cooling of Buildings, Iachetta, F. A. (Ed); Washington, DC, NSF, pp 145-147; 1975.

Johnson, G. R.; Winn, C. B., "Performance Comparison Between a Computer Performance Analysis Model and the Solar Heated and Cooled Laboratory". In 1975 International Solar Energy Cong. and Expo. pp 293-294; 28 July 1975.

Johnson, T. E.; Wellesley-Miller, S.; Chahroudi, D.; Brooks, "J.; Wagner, S.; Heeschen, C.; Bryan, D., "Exploring Space Conditioning with Variable Membranes". Report for January 1, 1974 - Apr 30, 1975. MIT, Cambridge, Mass. April, 1975. 117 pp; Apr 1975.

Johnson, T: E., "Radiation Cooling of Structures with Infrared Transparent Wind Screens". Solar Energy; 17: No. 3, pp 173-178; July 1975.

Johnson, V. H.; Kemp, A. J.; Lollar, R. B., "A Structured Design Process for Solar Energy Systems". IBM Huntsvilie; 1976.

Jones, I. R., "Environmental, Soclal, and Political Aspects of Solar Heating and Cooling of Buildings: A Report by TRW". Solar Heating and Cooling of Buildings, Iachetta, F. A. (Ed), Washington, DC; Pp 103-108. NSF; 1975.

Jones, I. R., "Technical and Economic Considerations: A Report by TRW". Solar Heating and Cooling of Buildings, Iachetta, F. A. (Ed), pp 22-30. Washington, DC; NSF ; 1975.

Jones, J. W.; Adams, J. R.; Carnes, T. N.; "Opportunities for Energy Conservation in Office Buildings". ASME; New York, 9 pp; 1976.

Jordan, R. C., "Heat Pump and Solar Energy - Their Roles in Space Conditioning". Indus. Refrig.; 133; No. 3, vp (Sep. 1957); Sep 1957.

Jordan, R. C. (Ed), "Low Temperature Engineering Application of Solar Energy". ASHRAE; 1967.

Jordan, R. C., "Place of the Heat Pump and Solar Energy In Space Conditioning". Proc. Am. Power Conf.; 39: pp 369-379 (1957); 1957.

Juppenlatz, M., "Design Principles for "Solar" Housing in Queensland". Arch. Sci. Rev.; 5: No. 1, pp 23-30; March 1952. 
Kaba, M. L., "Potential Utilization of Solar Energy in Guinea". Appl. Solar Energy (USSR) (Engl. Trans1.); 9: No. 4, pp 97-99; 1973.

Kakabayev, A.; Rakhmanov, A., "Absorption Solar Cooling System with Spray Chamber: Description and Test Results". Appl. Solar Energy (USSR) (Engl. Trans 1); 7: No. 4; pp 77-79; 1971.

Kakabayev, A.; Petrova, A. A., "Climate of Turkmenistan (Askhabad Data) in Relation to the Utilization of Solar Energy for Heating and Cooling". Appl. Solar Energy (USSR) (Eng1. Trans1.); 2: No. 6, pp 36-40; 1966.

Kakabayev, A.,. "Freon-Ejector Solar Refrigerator". Geliotekhnika; 2: No. 5; pp 37-43; 1966.

Kakabayev, A.; Golaev, M., "Glazed Flat Surface as a Solution Regenerator for Use in an Absorption Solar Cooling System". Appl. Solar Energy (USSR) (Engl. Trans 1.); 7: No. 6; pp 116-120; 1971 .

Kapur, J...., "Report on the Utilization of Solar Energy for: Refrigeration and Air Conditioning Applications". Solar Energy; 4: No.1, pp 39-47 (Jan. 60); Jan 1960.

Kauffman, K.; Pan; Y. C., "Congruently Melting Materials for Thermal Energy Storage in Air Conditioning". National Center for Energy Management and Power, Philadelphia, PA; Penn. State Univ., University Park, PA (Avail. NTIS); June 1973.

Kauffman, K.; Pan, Y. C., "Thermal Energy Storage in Sodium Sulfate Decahydrate Mixtures". Towne School of Civil and Mech. Eng., Penn. Univ., Phildelphia, PA, vp; (Avail. NTIS); Dec. 1972.

Kemp, A. J., "Data Monitoring and Information Availability - A Key to Solar Energy Utilization". Technology Today for Tomorrow; Proceedings of 12th Space Cong., Cocoa Beach, Fla., Apr 9-11, 1975. (A75-40601 20-12) Cocoa Beach, Fla., Canaveral Council of Technical Societies, 1975, pp 5-29 to 5-36; Apr 1975.

Kimura, K.; Udagawa, M.; Ohmura, G., "Exploring in House Cooling with Solar Energy Study on the Horizontal Parabolic Cylinder Type of Collector". From International Cong. on the sun in the Service of Mankind, UNESCO House, Paris, France; 2 July 1973.

Kimura, K., "Solar Energy as a Heat Source for Heating and Cooling Buildings". Nenryo Kyokai-Shi; 52: No. 559, pp 813-821; November 1973.

Kimura, K.; Tanaka, S., "Solar Heating, Cooling and Domestic Hot Water Supply at Soka Solar House". In 1975 International Solar Energy Cong. and Expo., pp 310-311; 28 July 1975.

Klein, S. A.; Cooper, P. I.; Freeman, T. L.; Beekman, D. M.; Beckman, W. A.; Duffie, J. A., "Method of Simulation of Solar Processes and Its Application". Solar Energy; 17: No.1, pp 29-37; Apr 1975. 
Klein, W. H.; Hickey, J: R., "Proceedings of Symposium on Solar Radiation Measurements and Instrumentation". Smithsonian Inst., Rockville, MD. 478 pp; 1973.

Klein, S. A.; Beckman, W. A.; Duffie, J. A., "TRNSYS - A Transient Simulation Program". Paper presented at ASHRAE meeting, Dallas, Texas. Feb 1976.

Klein, S. A.; et al, "TRNSYS - A Transient Simulation Program". Report No. 38, University of Wisconsin, Engineering Experiment Station. November 1975.

Knoll, R. H.; Hamlet, I. L.; Miao, D., "Initial Operation of a Solar Building Test Facility". (Abstract). In "Sharing the Sun! Solar Technology in the Seventies. Vol. 3"' Boer, K. W. (Ed) pp 136,137; 1976.

Koltun, M. M., "Selective Surfaces and Coatings in Solar Radiation Engineering". Scientific Translation Services, Santa Barbara, CA; Report No. NASA-TT-F14650, 23 pp; Jan 1973. 
La Plante, J. 0.; San Martin, R. L.; Smith, P. R., "Competively Priced Residence for Utilization of Solar Energy". ASME Paper No. 73-WA/SOL-3; 7 (1973). November 1973.

Lauck, F.; Myers, P. S.; Uyehara, 0. A.; Glander, H., "Mathematical Model of House and Sol-ar - Gas Absorption Cooling and Heating System". Trans. ASHRAE; 71: pp 273-285; 1965.

Lauch, F., "Mathematical Model of a House and Solar - Gas Absorption Cooling and Heating System". ASHRAE J.; 7: No. 7,. 52 (1965); 1965.

Lawrence, R. A., "Performance of Heat Pumps Using Cold-Side Energy Storage and Unconventional Heat Sources". ASME, New York, NY. 12 pp. 1974.

Leonard, J. A., "Sandia's Solar Total Energy Program". Materials Review 1975; Proceedings of the 7 th National Tech. Conf., Albuquerque, NM, Oct. 14-16, 1975. Supplement; pp 16-22; October 1975.

Leonard, J. A.; Thunborg, S., "Solar Total Energy Program Quarterly Report", July - Sept 1974. Sandia Labs.. Albuquerque, NM. Contract AT $(29-1)-789$. 81 pp; Dec 1974.

Littles, J. W.; Cody, J. C., "Considerations for Performance Evaluation of Solar Heating and Cooling Systems". NASA, MSFC, Huntsville, AI. (NASA TM X64969). 16 pp. Nov 14, 1975.

Littles, J. W.; Humphries, W. R.; Cody, J. C. (MSFC), "Design and Operation of a Solar Heating and Cooling System for a Residential Size Building".

1975 International Solar Energy Cong. and Expo. pp 356-357; 28 July 1975.

Littles, J. W.; Humphries, W. R.; Cody, J. C., "Design and Operation of a Solar Heating and Cooling System for a Residential Size Building". NASA, MSFC Huntsville, AL; 33 pp, Sep 1, 1975.

Littles, J. W.; Cody, J. C., "Factors to be Considered in the Development of Standards for Performance Evaluation of Solar Heating and Cooling Systems". NASA, MSFC, Huntsville, AL. 21 pp. October 21, 1975.

Liu, B. Y. H.; Jordan, R. C., "Analysis of Soalr Energy Data Applicable to Building Design": ASHRAE Journal; pp 31-41, 66; Dec 1962.

Liu, M. K.; Mundkur, P., "Numerical Simulation of the Effect of Climatic Conditions on Heat Transfer from a Building". ASME; New York, 5 pp; 1976.

Lof, G. 0. G., "Colorado State University Solar Heated and Cooled House". (Col. State Univ.) 1974. (Conf-740243-1); From Conference on Solar Cooling for Buildings; Los Angeles, CA. 6 Feb 1974.

Lof, G. O. G., "Cooling with Solar Energy". Proceedings of the World Symposium on Applied Solar Energy; pp 171-189. Menlo Park, CA; Stanford Research Institute. 1956. 
Lof, G. 0. G.; Tybout, R. A., "Design and Cost of Optimized Systems for Residential Heating and Cooling by Solar Energy". Sol. Energy; 16: No.. 1, pp 9-18; Aug 1974.

Lof, G. 0. G.; Ward, D. S.; Ward, J. C.; Smith, C. C., "Design and Construction of a Residential Solar Heating and Cooling System". Colorado State Univ., Fort Collins, CO. August 1974.

Lof, G. 0. G., "Design and Construction of a Residential Solar Heating and Cooling System". Semiannual Progress Report, 1 Jan - 31 July 1974.

Lof, G. 0. G.; Ward, D. S., "Design, Construction and Testing of a Residential Solar Heating and Cooling System". Progress Report, 1 September 1973 31 January 1974; I Mar 1974.

Lof, G. 0. G., "Heating and Cooling of Buildings with Solar Energy". Introduction to the Utilization of Solar Energy. Zarem, A. M. (Ed) New York; McGraw-Hill Book Co., Inc., pp 230-294; 1963.

Lof, G. 0. G.; "House Heating and Cooling with Solar Energy". In Solar Energy Research, University of Wiscons in Press, 1955.

Lof, G. 0. G., "Introduction to the Utilization of Solar Energy". Chapter 11 of Heating and Cooling of Buildings with Solar Energy". Zarem and Erway (Eds). McGraw-Hill; 1963.

Lof, G. 0. F., "Profits in Solar Energy". Sol. Energy; 4: No. 2, pp 9-15; Apr 1960.

Lof, G. 0. F., "Solar Cooling Design and Cost Study". Proceedings of the Solar Heating and Cooling for Buildings Workshop, Washington, DC. pp 119-125; 21 Mar 1973.

Lof, G. O. G., "Solar Heating and Cooling of Buildings: Background and Economic Factors". Energy, Environment, Productivity. Holmes, J. (Ed). Washington, DC; NSF (1974); pp 46-49; 1974.

Lof, G. 0. G., "Solar House: Colorado State University". Solar Heating and Cooling of Buildings, Iachetta, F. A. (Ed), Washington, DC NSF pp 133-141; 1975.

Lorsch, H. G., "Solar Heating/Cooling Projects at the University of Pennsylvania". Proceedings of the Solar Heating and Cooling for Buildings Workshop. Part I: Technical Sessions, Washington, DC. pp 194-210; Mar 1973.

Lukomskii, S. M.; Chukvyshkina, S. M.; Shkabel'nilova, L. P., "Economics of the Application of Semiconductor Heat Pumps for Room Heating and Cooling". Appl. Solar Energy (USSR) (Engl. Trans1); 6: No. 3, 45-47; 1970. 
Lukomskij, S. M.; Preizer, A. B.; Shvalev, L. I.; Shinko, P. F., "Results of Tests on Semiconductor Air-to-Air Heat Pumps for Air Conditioning". Appl. Solar Energy (USSR) (Engl. Trans1.); 5: No. 6, 80-1.

Lukomskii, S. M.; Editkin, E. R.; Korotrev, A. M. , "Thermoelectric Heating and Cooling Systems". Appl. Solar Energy (USSR) (Engl. Trans 1); 4: No. 1, PP 38-45; 1968.

Kukomskii, S. M., "Thermoelectric Semiconductor Heat Pumps". Appl. Solar Energy (USSR) (Engl. Trans 1); 5: No. 5, pp 31-32; 1969.

Lunde, P. J., "Solar Powered Desiccant Air Conditioning System". Annual Progress Report Covering the Period June 1, 1974 to December 31, 1974. Center for the Encironment and Man, Inc., Hartford, Conn. 31 p.p. 31 Jan 1975.

Lunde, P. J., "Solar Powered Desiccant Air Conditioning System". Final Report, June 1 - Dec 31, 1974. Center for the Environment and Man, Inc., Hartford, Conn., 139 pp' 1 Apr 1975.

Lunde, P. J., "Solar Powered Desiccant A1r Conditioning System". Phase II Quarterly Progress Report. August 1975. 
Maag, W.L., "Solar. Energy to Heat and Cool a New NASA Langley Office Building", September 1974, Pp 22, (NASA-TM-X-71615; E-8103).

Mackillop, A, "Low Energy Building-Why and How"; Building Technology and Management; p 5, January 1973.

Macklis, S.L.; Haas, S.A., "An Integrated Solar Heated and Cooled Mobile Home", In Energy see 10; 10th Annual Intersociety Energy Conversion and Engineering Conference, Newark, Del., August 18-22, 1975. Record. (A7545920 23-44) New York, IEEE, Inc., 1975, pp 38-42, August 1975.

Macriss, R.A., "Selecting Refrigerant-Absorbent Fluid Systems for Solar Energy Utilization", Paper Presented at Ashrae Meeting, Dallas, Texas, February, 1876.

Magee, J.J.; Brazil, J.R.; Stolzenburg, W.A., "Design and Cost Tradeoffs in Heavily Insulated Solar Heated and Cooled Homes, "In 1975 Intn' I Solar Energy Cong. and Expo., pp 39-40, Rockville, Mo.; ISES, 1975.

Magee, J.J.; Brazil, J.R.; Stolzenbur, W.A., "From Fossil Fuel to Solar Heating and Colling Systems in American Homes: An Analysis of Local, State, and Federal Legislation", In 1975 Intn'I Solar Energy Cong. and Expo. Rockville, Md., ISES. pp 17-18, 1975.

Magnus, H.L., "Solar Energy Projects of the Federal Government", Fed. Energy Admin., Office of Energy Data Policy, Washington, D.C. (Avail. NITS), 151p, January 1975.

Marshal1, B.W., "Analysis of a 1000-Home Solar Total Energy Community Using Clear Air Solar Intensity", Sandia Labs., Livermore, Ca. Contract at (29-1)-789, May 1975.

Maycock, P.D.; Herwig, L.0.; Bezdek, R.H., "Prospectus on Commercialization of Solar Heating and Cooling Systems", In "Sharing the Sun! Solar Technology in the Seventies. Vol. 1"; Boer, K.W. (Ed), pp 151-164, 1976.

Meinel, A.B., "Optical Interfaces in Solar Energy Utilization". In Effective Systems Integration and Optical Design; Proceedings of the Seminar, San Diego, Ca., August 21-23, 1974, (A75-37330 17-35) Palos Verdes Estates, Ca., Society of Photo-Optical Instrumentation Engineers, 1975, pp 12-16, August 1974.

Merrick, R.H.; English, R.A., "An Air-Cooled Absorption Cycle," Paperpresented at Ashrae Meeting, Vancouver, B.C., 1960.

Merrick, R.H.; Anderson, P.P., "Design, Evaluation and Recommendation Effort Relating to the Modification of a Residential 3-Ton Absorption Cycle Cooling Unit for operation with Solar Energy," Nov. 1973, Contract NAS8-25996, (NASA(R-1202T). 
Miles, F.G., "Cooling With Solar Energy," J. Inst. Heating and Vent. Engrs.; 27: 97-107, JuTy, 1959.

Miller, D.K., "Performance of Water Cooled Lithium Bromide Absorption Units for Solar Energy Applications," Heat, Piping Air Cond. ' 48: No. 1, pp 45-51, 1 January 1976.

Miller, R.D., "Supplementary Solar Energy Diet for the Wait Watchers", Build. Syst. Des.; 72: No. 5, 13-15, 1975.

Miller, S.W.; Chahroudi, D., "The Integration of Solar Space Condidioning and Building Design"., MIT, Cambridge, Mass. 17p., 1975.

Mingazov, R.F.; Rodimkin, E.D., "Cooling-Load Characteristics for Residential and Public Buildings in the Cities of Central Asia," Appl. Solar Energy (USSR) (Engl. Trans1.); 9: No. 4, 117-122, 1973.

Moesta, H., "Heating and Cooling by Solar Energy: Environmentally-Safe Methods of Latent Energy Storage", Umwe1t; No. 6, 5p (1972), 1972.

Moore, D.C. "Solar Residential Demonstration Program", In "Sharing the Sun: Solar Technology in the Seventies. Vol. 1", Boer, K.W. (Ed), pp 91-100, 1976.

Moore, G.L., "Theoretical Investigation and Experimental Verification of the Two-Phase Heat Transfer Characteristics of a Combined Solar Collector-Generator for a Solar Air Conditioner," Univ. of Florida, Gainesville, Fla. 115p, 1967, PhD Thesis.

Morgan, Bruce H., "Cost Benefit of Utilizing Thermal Storage for Peak Cooling Power Leveling", Envir. Protection R\&D Team, U.S. Naval Academy, Annapolis, MD. 21p, September, 1975.

Morimura, P.T.; Ishida, Y., "An Analys is on Optimal Design of Solar Heating and Cooling System for School", In "Sharing the Sun! 5olar Technology in the Seventies. Vo1. 3"; Boer, K.W. (Ed) pp 356-37.0, 1976.

Morrison, C.A.; Farber, E.A., "Application of Solar Energy to Residential Dwellings", Build, Syst. Des.; 71: No. 3., 49-52, April-May, 1974.

Morrison, P.; Farber,. E., "Solar Energy Applied to Residential Dwellings", Univ of Florida, 13p, 1974.

Mnrse, F.H., "CCMS Solar Energy Pilot Study". In 1975 Intn'l Solar Energy Cong. and Expo., Rockville, Md.; ISES (1975), pp 6-7, 1975.

Morse, F.H.; Simmons, M.K., "Solar Energy-Energy Conversion Technology", Annual Revfew of Energy, Vol. 1 (A76-30101 13-44) Palo A1to, Ca.., Annual Reviews, Inc., 1976. 
Morse, F.H.; Balcomb, J.D.; Perry, J.E., Jr., "The Current Technology for Solar Heating and Cooling", In "Sharing the Sun! Solar Technology in the Seventies.. Vol. 1"; Boer, K.W. (Ed), pp 142-150, 1976..

Morse, F.H.; Allen, R.W.; Anand, D.K.; Bazques, E., "Thermal Performance Predictions of a Solar Absorption Air Conditioning System", In 1975. Intn'1. Solar Energy Cong... and Expo. pp 390-391, 28 July 1975.

Mueller, R., "Energy Conservation Alternatives to Nuclear Power, a Case Study", NASA, Goddard Space Flight Center, 1973.

Mullick, S.C.; Bupta, M.C., "Atmospheric Solar Brine Regenerator", Indian Inst. of Tech., Madras pp 410-411, 1975 ISES, 28 July 1975, Rockville/ Los Angeles.

Mullick, S.C.; Gupta, M.C., "Simple Method for Desorption of Water by Solar Heating of the Absorbent Solution Used for Dehumidification of Room Air, From Intn' 1 Cong. on the Sun in the Service of Mankind; UNESCO House, Paris, France, July, 1973.

Mullik, S. Ch.; Gupta, M.S., "Simple Method for the Desorption of Water Using Solar Radiation for Heating the Absorbing Solution", Appl. Solar Energy (USSR) (Eng. Trans1.); 10: No. 3-4, 52-5, 1974.

Mullick, S.C.; Gupta, M.C., "Solar Desorption of Absorbent Solutions", Solar Energy; 16: No. 1, 19-24, (Aug. 1974), August, 1974.

Murray, H.S.; Kuckertz, T.H., "Dynamic Simulation of a Solar Heated and Cooled Building", Los Alamos Scientific Lab., Los Alamos, N.M. 9p (Conf-750713-5), (Avail. NTIS), 1975.

Murray, H.S.; Shipley, J.P., "Models for Solar Heating and Cooling Systems in Buildings", In 1975 Intn'1 Solar Energy Cong. and Expo. pp 276-277, 28 July 1975.

McCormick, P.0:, "Modifications to the Lockheed-Huntsville Solar Heating and Cooling Systems Simulation Program", Lockheed Misstles and Sjace Co., Inc., Huntsville, Ala., 46p, 7 July 1975.

McCulloch, W.H.; Lee, D.0.; Schimmel, W.P., Jr., "The Solar Community-Energy for Residential Heating, Cooling, and Electrical Power", In Energy Delta Supply vs Demand; Proceedings of the Energy Symposium, San Francisco, Ca., February 25-27, 1974, (A75-27778 11-44) Tarzana, Ca., AAS, 1975, pp 389-410, February, 1974 .

McGee, R.P.; Rannels, J.E.; York, C.I., "Solar Energy Program Plan for Heating and Cooling Buildings", Atmoic Energy Commission, Div. of Headquarters Service, Washington, D.C. (Avail. NTIS), 1974. 
Nakahara, N.; Miyakawa, Y.; Yamamoto, M.; "Experimental Study on House Cooling and Heating with Solar Energy Using Flat Plate Collector", In 1975 Intn'1 Solar Energy Cong. and Expo. pp 358-359, 28 July 1975.

Namkoong, D. "Performance of a Libr Water Chiller in a Laboratory-Scale, Experimental Solar System Test Loop (Abstract)", In "Sharing the Sun! Solar Technology in the Seventies, Vol. 3".; Boer, K.W. (Ed)., pp 44, 45, 1976.

Newton, J.; "Meeting U.S. Energy Requirements: Solar Energy's Potential Share", Ashrae J.; pp 36-40, November, 1975.

Niles, P.W., "Thermal Evaluation of a House Using a Movable Insulation Heating and Cooling System", In 1975 Intn'1 Solar Energy Cong. and Expo., pp 338-339, 1975.

Notestein, J.E., "Operational Experience-Solar Heating a Boston School", In Energy see 16; 10th Annual Intersociety Energy Conversion and Engineering Conference, Newark, De 1., August 18-22, 1975, Record, (A75-45920 23-44) New York, IEEE, Inc., 1975, pp 14-18, August, 1975.

Oakley, C.G., "Use of Solar Energy in Buildings in New York State, Final Report, Oct., 1973-April, 1974", Newyork State Assembly Scientific Staff, Albany, N.Y.; Syracuse Univ., N.Y. (Avail. NTIS), 75N17825.

O'Ne111, M.J.; McDanal, A.J.; Sims, W.H., "Development of a Residential Heating and Cooling System Using NASA Derived Technology", Lockheed Missiles and Space Co., Huntsville, A1., Contract NAS8-25986, 99p, (NASA-CR-124063; LMSC) AHREC-D306275; HREC-5896-3), November, 1972.

O'Neill, M.J.; McCormick, P.0.; Kruse, W.R., "Development of a Solar Powered Residential Heating and Cooling System, Final Reprot", July, 1974, Contract NAS8-25986, 95p, (NASA-CR-120400), (LMSC/HREC-TR-D-390138).

Ontga, T., "Absorption Cooling Unit with Fixed Conoidal Reflector". Procepedings of U.N. Conf. on New Sources of Energy, Vol. 6 pp 41-50 (1964), 21 August 1961.

Oonk, R.L.; Beckman, W.A.; Duffie, J.A., "Modeling of the CSU Heating/Cooling System-Color-Add State University Solar House Computer Simulation". Solar Energy, Vol. 17, Apri1, 1975, pp 21-28, April, 1975.

Orlowski, H., "Corrosion Protection for Solar Systems", Heat., Piping, Air Cond.; 2p, July, 1976.

Page, J.K.. "Solar Energy and Architecture". Proceedings of the Royal Institution of Great Britain, Vol. 47, 1974, pp 303-348, 1974.

Patton, A.R., "Solar Energy for Heating and Cooling of Buildings", Noves Data Corp., Park Ridge, N.J. (Energy Technology Review, No. 7), 337p, 1975. 
Peker, Ya. D., "Method for Engineering and Economic Estimates for the Facades of Buildings Designed with Air Conditioning". Appl. Solar Energy (USSR) (Engl. Tran 1.); 8: No. 1, 48-55, 1972.

Penrod, E.B.; Prasanna, K.V., "Analysis of a Proposed Solar-Earth Heat Pump", Bulletin No. 74, Univ. of Kentucky, 111p, December, 1974.

Penrod, E.B.; Prasanna, K.V., "Procedure for Designing Solar-Earth Heat Pumps", Heat. Piping Air Con.; 41: No. 6, 97-100, June, 1969.

Perry, E.H., "The Theoretical Performance of the Lithium Bromide-Water Intermittent Absorption Refrigeration Cycle", Solar Energy, Vol. 17, November, 1975, pp 321-323, November, 1975.

Pescod, D. "Performance of Air-to-Air Heat Exchangers with Moulded Plastic Plates", Melbourne, Australia; Commonwealth Scientific and Industrial Research Organization, vp., 1973.

Prescod, D., "Unit Air Cooler Using Plastic Heat Exchanger with Evaporatively Cooled Plates", Aust. Refrig. Air Cond. Heat.; 22: No. 9m 22-26; September, 1968.

Pesko, C.M. (Ed), "Solar Directory 1974", Environ. Action of Colorado, Univ. of Col. (1975), 6067p, 1975.

Petersen, H.C., "Comparison of Market Capture Potential of Single vs Multiple Structure Solar Energy Space Conditioning: 1975-2020", In 1975 Intn'1 Solar Energy Cong. and Expo. pp 33-34, Rockville, MD; ISES, 1975.

Peterson, H.C., "Dynamic Analysis of Economics of Scale in Space Heating and Cooling. Annual Progress Report Covering the Period Sep. 1, 1974Dec. 31, 1974", Utah State Univ., Logan, Utah, 7p, 28 January 1975.

Pleijel, G. "Solar Energy", Stockholm, Sweden; Aldus, 100p, 1966.

Pogany, D.; Ward, D.S.; Loef, G.O.G., "Economics of Solar Heating and Cooling Systems", In 1975 Intn "I Solar Energy Cong. and Expo., pp 29-30, ISES, Rockville, MD., 1975.

Pollard, W.G., "The Long-Range Prospects for Solar Energy", American Scientist; 64: pp 424-429, July-August, 1976.

Pope, R.B.; Schimmel, W.P., Jr.; Lee, D.0.; ET AL, "Combination of Solar Energy and the Total Energy Concept: The Solar Community", Proceedings of 8th Intersoclety Energy Conversion Engineering Conference, AIAA, New York, pp 304-311, 1973. 
Pope, R.B.; Schimmel, W.P., Jr.," "Solar Community and the Cascaded Energy Concept Applied to a Single House and a Small Subdivision", Sandia Labs., Albuquerque, N.M., 35p, May 1973.

Porter, J.M., "The Use of Commerically Available Absorption Units on Solar Powered Cooling Systems", Paper presented at Ashrae Meeting, Dalls, Texas, February, 1976.

Prigmore, D.R.; Barber, R.E., "A Prototype Solar Powered, Rankine Cycle System Providing Residential Air Conditioning and Electricity", Proceedings of 9th Intersociety Energy Conversion Engineering Conference, San Francisco, Ca.; August, 26-30, 1974 (A75-10476 01-44) New York, ASME, 1974, pp 326-333, August, 1974.

Prigmore, D.; Barber, R., "Cooling with the Sun;s Heat-Design Considerations and Test Data for a Rankine Cycle Prototype", Solar Energy, Vol. 17, July, 1975, pp 185-192, July, 1975.

Ragsdale, R.G.; Namkoong, D., "NASA Langley Bullding Solar Project and the Supporting Lewis Solar Technology Program", NASA, LRC, Cleveland, Ohio, 34p, (NASA-TM-X-71600; E-8075), 1974.

Rainer, G. "Office Tower Reaches for the Sun", Build. Syst. Des.; 72: No. 5, $16(1975), 1975$.

Ramsey, J.W.; Borzoni, J.T.; Holland, T.H., "Development of Flat-Plate Solar Collectors for the Heating and Cooling of Buildings: Final Report", Honeywell. Inc., Minneapolis, Minn. (Avail. NTIS), 75N26495.

Rauch, J.S.; Wood, B.D., "Steady-State and Transient Performance of the ARKLA Solair Absorption Cooling System". In "Sharing the Sun! Solar Technology in the Seventies, Vol. 3"; Boer, K.W. (Ed), pp 387-405, 1976.

Redfield, A., "Proceedings of the Solar Heating and Cooling for Buildings Workshop, Part 1: Technical Sessions, March 21 and 22", Dept. of Mech. Engng., Maryland Univ., College Park, MD. July, 1973, 231p, (PB-223586; NSF-RA/N-73-004)", July, 1973.

Ruzzi, A.M.; Costello, D.; Noland, M.C.; "Choosing Alternative Energy Systems", In 1975 Intn'1. Solar Energy Cong. and Expo., pp 41-42, ISES, Rockvilie, MD., 1975.

Robertson, P., "Evaluation of Air Conditioning Energy Costs", Build. Serv. Eng.; V. 42, pp 195-198, November, 1974.

Rogers, B.T., "Using Nature to Heat and Cool", Build. Syst. Des.; 70: No. 7, 11-15, (October-November, 1973), 1973. 
Romancheck, R., "A Technical, Economic and Environmental Assessment of Utilizing Solar Energy for Heating/Cooling and Energy Conversion", International Energy Engineering Congress, Chicago, I11., November 4, 5, 1975, Paper, 9p, 76A20567.

Rosenbaum, B.B.; Davisson, J.W.; Pasternak, J., "Status Report on Termoelectricity, Part II, Devices, (Ninth Quarterly Review, Part 2)", Naval Research Lab., Washington, D.C., 163p, (NRL-Memo-1361), January, 1963.

Rousseau, J.; Hwang, K.C., "Development of a Solar-Powered Residential Air Conditioner System Optimization Preliminary Specification", Contract NAS830758 for MSFC. Garrett Air-Esearch Manufacturing Co., of Calif., November 7. 1975.

Ruegg, R.T., "Solar Heating and Cooling in Buildings: Methods of Economic Evaluation", Nat'1 Bureau of Standards, Washington, D.C., 41p, July, 1975.

Rueth, N., "Solar Energy: A Dream Becomes a Reality", Mech. Eng.; 97: No. 2, 69-71, February, 1975.

Rush, W.F.; Wurm, J.; Wright, L.; Ashworth, R.A., "Description of the SolarMec Field Test Installation", In 1975 Intn'l Solar Energy Cong. and Expo. pp 405-406, 28 July, 1975. 
Sakai, I.; Takagi, M.; Terakawa, K.; Ohue, J., "Solar Space Heating and Cooling with Bi-Heat Source Heat Pump and Hot Water Supply System". "In 1975 Intn'I Solar Energy Congress \& Expo. pp 415-416;28 JuT 175.

San Martin, R. L.; Couch, W. A., "Modeling of Solar Absorption Air Conditioning". Proceedings of 21st Annual Technical Meeting, Institute of Environmental Sciences, Anaheim, CA, April 14-16, 175. Vol. 1, pp 186-189. (A75-34926 16-31). Mount Prospect, IL, Inst. of Env. Sciences; Apr 75.

San Martin, R. L., "Solar Heating and Cooling at New Mexico State University". Proceedings of 15th Annual ASME Symposium, Aibuquerque, NM. ASME, New York, NY; 197.5 .

Sargent, S. L.; Teagan, W. P., "Compression Refrigeration from a Solar-Powered Organic Rankine-Cycle Engine". ASME Paper No. 73-WA/SOL-8; 8. From ASME Meeting; (11-15 Nov '73); 1973.

Sargent; S. L., "Proceedings of the Workshop on Solar Collectors for Heating and Cooling of Buildings". Dept. of Mech. Engr'ng., Maryland Univ., College Park, MD (Avail NT15); May' 75.

Sargent, S. L., Beckman, W. A., "Theoretical Performance of an Ammonia-Sodium Thiodyanate Intermittent Absorption Refrigeration Cycle". Solar Energy; 12:137; 1968.

Saypalia, W. E., Jr., "Solar Energy Heating and Cooling System". U. S. Patent 3,910,490. 7 Oct 175. Filed Date 21 Mar '74. 4 pp; Oct 175.

Schlesinger, R. J., "Hybrid Simulation of Solar HVAC System for House Retrofit Design. Semiannual Progress Report, 1.Jul - 31 Dec '74". Robert J. Schlesinger, Tarzana, CA (Avail NTIS).

Schmidt, R. N., "Transportable Solar Laboratory". Solar Heating and Cooling of Buildings. Iachetta, F. A. (Ed.) pp 142-144. Washington, DC; NSF; 1975.

Schoen, R., "Solar Energy Demonstrations and their Impacts". In 1975 Intn'] Solar Energy Congress and Expo. PP 23-24: Rockville, MD; ISES; 1975.

Scott, J. E.; Melicher, R. W.; Sciglimpaglia, D. M., "Demand Analysis Solar Heating and Cooling of Buildings. Phase I Report, Section I: Solar Water Heating in South Florida: 1923-1974. Section II: Lending Institution Attitudes toward Solar Heating and Cooling of Residences". Dec '74. 169 pp. Stock No. 038-000-00207-4;

Scott, R. D., "The United States National Program for the Demonstration of Solar Heating and Cooling in Buildings; Progress Report". In "Sharing the Sun! Solar Technology in the Seventies. Vol. 1"; Böer, K. W. (Ed.) pp 126-141; 1976. 
Seely, J., "Radiation Heat Transfer". IBM, Poughkeepsie, NY; Oct '75.

Seemens, M. G.; Wilbur, P. J.; Duff, W. S., "Liquid Refrigerant Storage in Absorption Air Conditioners". Paper No. 74-WA/HT-19. ASME (1974) 12 pp; 1974.

Sepsy, C. F., "Thermodynamic Simulation of a Building Environmental Controi System". From Proceedings of the Solar Heating and Cooling for Buildings Workshop; Wash., DC. Mar 21-23, '73. Part I: Technical Sessions; 21 Mar 173.

Shavit, G., "Solar Gain Control". Heating, Piping Air Cond.; 47:3, pp 85-91; Mar 175.

Sheklein, A. V.; Shafeeva, K. A., "Methods of Technical Prediction in Solar Engineering". Geliotekhnika; 8:5, pp 61-68; 1972.

Shelton, S. V., "A Solar Heating System Utilizing a Liquid-Liquid Electric Chiller for Heating and Off-Peak Electric Cooling (Abstract)". In "Sharing the Sun! Solar Technology in the Seventies. Vol. 3"; Böer, K. W. (Ed.). pp $371-372 ; 1976$.

Sheridan, N. R., "Energy Conservation Applied to the Rational Design of a. Dwelling for the Tropics". Paper 54 from World Power Conf; Lausanne (1964); 1964.

Sheridan, N. R.; Juler, P. A., "Engineering of 'SOLAIR' Experimental House". Arch. Sci. Rev.; 5:1, pp 31-38; Mar '62.

Sheridan, N. R., "Performance of the Brisbane Solar House". Solar Energy; 12:4, pp 395-401; Jul 152 .

Sheridan, N. R., "Prospects for Solar Air Conditioning in Australia". Proceedings of the United Nations Conference on New Sources of Energy. Vol. 6 pp 87-97. New York; United Nations; 1964.

Sheridan, N. R., "Prospects for Solar Energy in Northern Australia". J. Inst. Eng., Aust.; 43:9, pp 11-15 (Sep. 71); Sep i71.

Sheridan, N. R., "Solar Air Conditioning". J. Inst. Engrs.; 47-51 (Jan-Feb '61); 1961.

Sheridan, N. R.; Duffie, J. A., "The Part-Load Performance of an Absorption Refrigerating Machine". Supp. Rul1, Inst. Int. nu Frord, 381; 1965.

Sherman, J., "Residential Solar Demonstration Program". Energy Technology II, pp 180-184. Sullivan, T. F. P. (Ed.). Washington, DC. Government Institutes, Inc.; 1975.

Shipley, J. P., "Control Systems for Solar Heated and Cooled Buildings". In 1975 Intn'l Solar Energy Congress \& Expo. pp 387-388; 28 Jul '75. 
Shipley, J. P., "Control Systems Design and Simulation for a Solar Cooled Building". Los Alamos Scientific Lab, Los Alamos, NM. 11 Pp:. (CONF-750713-4); 1975.

Shvaleva, 0. L.; Zakhidov, R. A.; Avezov, R. R., Use of Solar Heat Pumps for Heating and Air Conditioning - A Brief Survey". Applied Solar Energy, Vol, 11, No. 1-2, 1975, pp 55-60 (Translation); 1975.

Simmons, M.; Wolgast, R.; Wahlig, M., "Ammonia-Water Absorption Air Conditioner". In 1975 Intn'l Solar Energy Congress \& Expo. pp 400-401; 28 Jul 175.

Speiser, K.; Diamond, E., "The Energy House". ASHRAE d.; pp 68-71; Nov '75.

Spencer, D. F.; Greenburg, A. B., "Roles ofr Solar Thermal Conversion Systems in Our Energy Economy". Energy Delta Survey vs Demand; Vol. 35, pp 359-388. AAS Publications Office, Tarzana, CA; 1974.

Spielvoge1, L. G., "Solar Energy: Application Guidelines". ASHRAE J.; Pp 44-46; Nov 175.

Spreyer, E., "Solar Buildings in Temperate and Tropical Climates". Proceedings of the United Nations Conference on New Sources of Energy. Vol. 5, pp 418-423. New York; United Nations; 1964.

Starr, C., "Solar Technology Gets New Priority in ERDA Plan for Energy RD and D". Prof. Eng.; 45:8, pp 16-19; Aug '75.

Stickney, G. H., "Wind/Solar Energy Investigation, A Feasibility Study (Ph. D. Thesis)". Kansas Univ., Lawrence, Kan. (Avail. Univ. Microfilms Order No. $76-1311) ; 1975$.

Stoecker, W. F. (Ed.), "Procedures for Simulating the Performance of Components and Systems for Energy Calculations. Third Edition". ASHRAE, New York, NY. 96 pp. 1975.

Streed, E. R., "The Relationships Between Tests on Components Separately to Tests on Performance of Solar Total Systems or Installations". Paper from the Conference on Standards for Solar Heating and Cooling, ASTM Hdqrtrs, Philadelphia, PA; Oct'14-15, '75.

Stromberg, R. P., "Solar Community". Proceedings of the Solar Heating and Cooling for Buildings Workshop. Part I: Technical Sessions, Pp 164-170; Washington, DC; Mar 173.

Stromberg, R. P., "Total Energy Solar Systems". Trans. Am. Nuc1. Soc.; $21: 142$; Jun 173.

Supple, R. G., "Solar Piping Considerations". Heating, Piping, Air Cond., pp 62-64; JuI 176.

Swartman, R. K., "Combined Solar Heating/Cooling System". In 1975 Intn'1 Solar Energy Congress \& Expo. pp 404-405; 28 Ju 175. 
Tabor, H., "Use of Solar Energy for Cooling Purposes". Solar Energy; 6:4, pp 136-142 (Oct - Dec '62); 1962.

Tabor, H., "Use of Solar Energy for Cooling Purposes". Proceedings of UN Conf. on New Sources of Energy. Vol. 6, pp 3-8. New York, UN; 1964.

Tasker, C., "Research for Heating, Ventilating and Air Conditioning Engineer". Heating, Vent. Air Cond. J: 16:324, 345; Nov ' 48.

Tasker, C., "Solar Energy - Its Role in Heating and Cooling". Heat. Vent. Eng. and J. Air Cond.; 24:280,143; 1950.

Tchernev, D. I., "Exploration of Molecular Sieve Zeolites for the Cooling of Buildings with Solar Energy. Semi-Annual Progress Report Covering the Period Sep 1 - Dec 31, '74". Lincoin Lab, MIT, Lexington, Mass 31 Jan '75; Jan '75.

Teagen, W. P.; Sargent, S. L., "A Solar Powered Combined Heating/Cooling System with the Air Conditioning Unit Driven by an Organic Rankine Cycle Engine". Paper No. EH-94-1 presented at the ISES Paris Conference, Paris, France; Jul ' 73.

Teagen, W. P., "Solar Powered Heating/Cooling System with the Air Conditioning Unit Driven by an Organic Rankine Cycle Engine". Proceedings of the Solar Heating and Cooling for Buildings Workshop. Part I: Technical Sessions, pp 107-111; Washington, DC; Mar '73.

Telkes, M., "Energy Storage Media". Proceedings of the Solar Heating and Cooling for Buildings Workshop. Part I: Technical Sessions, pp 57-59; Washington, DC; Mar 13.

Telkes, M., "Low-Cost Solar Heated House". Heating and Vent.; 47:No. 8, pp 72-74; Aug ' 50.

Telkes, M., "Solar Heating and Cooling". From 3rd Conf. on Large Scale Solar Energy Conversion for Terrestrial Use; Delaware (8 0ct. 171); Oct 171.

Telkes, M., "Storage of Solar Energy for Heating and Cooling". Klima Kaelteing; 2:No. 11, pp 465-470; 1974.

Telkes, M., "Storage of Solar Heating/Cooling". ASHRAE Trans.; 80:No. 2, pp 382-392. Also in Solar Energy Applications; ASHRAE, New York; 1974.

Tenelius, F., "Solar Radiation Effects on Room Conditioning". Byggnaestaren; No. $3(1960) ; 1960$.

Terrill, W. R.; Kirpich, A.; Hittle, D. C., "Solar Heating and Cooling of Army Buildings". In Energy 10; 10th Annual Intersociety Energy Conversion and Engineering Conference, Newark, Del, Aug 18-22, 174. Record. (A75-45920 23-44) New York, IEEE, Inc., 1975, pp 29-37 (Also separately filed copy); Aug '75.

Thomas, R. L., "The Utilization of Solar Energy to Help Meet Our Nation's Energy Needs". Lewis Research Center, Cleveland, OH. N73-22748. NASA-TMX68230; 1973. 
Thomas W. A.,. "Proceedings of the Workshop on Solar Energy and the Law. Feb. 10, '75. Arlington, VA". American Bar Foundation, Chicago, IL 32 pp (CONF-750238-). (Avail NTIS); Mar 75.

Thomason, H. E., "Experience with Solar Houses". Solar Energy; 10:1, pp 17-22; Jan - Mar ' 66.

Thomason, H. E., "Solar-Heated House Uses 3/4 HP for Air Conditioning". ASHRAE J.; Nov ' 62.

Thomason, H. E. (Edmund Scientific Co.), "Solar Houses and Solar House Models.

Thomason, H. E.; Thomason, H. J. L, Jr., "Solar House Heating and Air-Curiditiuning Systems: Comparisons and Limitations". Edmund Scientific Co., Barrington, NJ. $62 \mathrm{pp} ; 1974$.

Thomason, H. E.; Thomason, H. J. L, Jr., "Solar Houses/Heating and Cooling Progress Report". Solar Energy; 15: No. 1, pp 27-39 (May 173); May ' 73.

Thomason, H. E., "Solar Space Heating and Air Conditioning in the Thomason Home". Solar Energy; 4: No. 4, 11-19; Oct '60.

Thomason, H. E., "Solar Space Heating, Water Heating, Cooling in the Thomason Home". Proceedings of UN Conf. on New Sources of Energy. Vol. 5, pp 224-232. New York; UN; 1964.

Thomason, H. E.; Thomason, H. J. L., Jr., "Thomason Solar Homes". Proceedings of the Solar Heating and Cooling for Buildings Workshop. Part I: Technical Sessions, pp 180-184; Washington, DC; Mar 73.

Thomason, H. E., "Three Solar Houses". ASME Paper 65-WA/SOL-3. New York; ASME $9 \mathrm{pp}$; 1965.

Threlkelo, J. L., "Solar Energy as a Potential Heat Source for the Heat Pump". Univ. of Minn., Minneapolis, MN. 274 pp. Univ. Microfilms Order no. 5566 (Ph. D. Thesis); 1953.

Thring, J. B.; Smith, G. E., "Integrated Power, Water, Waste, and Nutrient System". Proceedings of .9th Intersociety Energy Conversion Engineering Conf.; San Francisco, CA, 26 Aug '74. ASME; New York. pp 259-263; 1974.

Trombe, F.; La Bianchetais, C. H., "Principles of Air-Conditioning in Countries with a Clear Sky". Proceedings of the UN Conf. On New Sources of Energy. Vol 6, pp 123-135. New York; UN; 1964.

Trombe, F.; Foex, M., "Utilization of Solar Energy for Simultaneous Distillation of Brackish Water and Air Conditioning of Hot-Houses in Arid Regions". Proceedings of UN Conf. on New Sources of Energy, Pp 104-109. Vo1. 6. New York, UN; 1964. 
Udagawa, M.; Kimura, K. I.; "Theoretical Study on the Performance of Horizontal Parabolic Cylinder Type Collector for Solar Cooling". Heat Transfer - Japanese Research, Vol. 4, Oct - Dec 175, pp 1-22 (Translation); 1975.

Vernon, R. W., "Summary of NASA-Lewis Research Center Solar Heating and Cooling and Wind Energy Programs". Paper from Univ. of AL, Southeastern Conference on Application of Solar Energy, Huntsville, AL. 23 pp; Mar 24-26, 175.

Vernon, R. W., "Summary of NASA Lewis Research Center Solar Heating and Cooling and Wind Energy Programs". NASA Lewis Research Center, Cleveland, $\mathrm{OH}$ (avail NTIS); 1975.

Von Allmen, E.; et al., "Space Conditioning with Solar Energy". Harvard Business School; Manufacturing Group No. 4. 71 Pp (Ph. D. Thesis); Apr '57.

Vook, F. L.; Schuler, D. G., "Integration of Photovoltaic and Solar Thermal Energy Conversion Systems". Sandia Labs, Albuquerque, NM (Avail NTIS); 1974.

Wahlig, M., "Control System for Combined Solar Heating and Cooling Systems. Progress Report No. 1: June 21, 1974 - December 31, 1974". California Univ., Berkley, CA; 31 Jan 75.

Wahlig, M.; Binnall, E.; Dols, C.; Graven, R.; Selph, F.; Shaw, R.; Simmons, M., "Control System for Solar Heating and Cooling". In 1975 Intn'l Solar Energy Congress \& Expo pp 383-384; 28 Jul ' 75.

Walters, S., "Energy-Saving Building Design". Mech. Eng.; 97:No. 2, 37-38; Feb' 75 .

Ward, D. S.; Uesaki, T.; Lof, G. 0. G., "Cooling Subsystem Design in CSU Solar House III". In "Sharing The Sun! Solar Technology in the Seventies. Vol. 3"; Böer, K. W. (Ed.). pp 68-89; 1976.

Ward, D. S.; Loef, G. 0. G., "Design and Construction of a Residential Solar Heating and Cooling System". Solar Energy, Vol. 17, Apr 175, pp 13-20; Apr '75.

Ward, D. S.; Loef, G. 0. G., "Design, Construction, and Testing of a Residential Solar Heating and Cooling System. Annual Progress Report, 1 Jul '74 - 1 Feb '75". Solar Energy Appl. Lab., Colorado State Univ., Fort Collins, Co. 64 pp; 1 Sep 175.

Ward, D. S.; Wagner, D. G.; Smith, C. C.; Loef, G. 0. G., "Design of Solar Heating and Cooling Systems for CSU Solar Houses II and III". In 1975 Intn'I Solar. Energy Congress \& Expo: pp 312-313; 28 Jul 175.

Ward, D. S.; Smith, C. C.; Ward, J. C., "Operational Modes of Solar Heating and Cooling Systems". In 1975 Intn'i Solar Energy Congress \& Expo pp 364-365; 28 Jul' 75. 
Ward, D. S.; Lof, G. 0. G:; "Performance of a Residential Solar Heating and Cooling System. Annual Progress Report. 1. Jul '74 - I Feb '75". Solar Energy Appl. Lab., Colorado State Univ., Fort Collins, C0. 62 pp; Jun ' 75.

Ward, D. S.; Loef, G. 0. G.; Smith, C. C.; Weiss, T., "Performance of the CSU Sol'ar House I Heating and Cooling System". In 1975 Intn'I Solar Energy Congress \& Expo. pp 346-347; 28 Jul 175.

Ward, D. S. (Col. State Dept. of Pub. HIth., Denver), "The Colorado State University Solar Heated and Cooled House". In Workshop on Solar Collectors for Heating and Cooling of Buildings; New York, NY 30 Jun 175. pp 48-54. (CONF-741141-3); 21 Nov 174.

Ward, J. C., "Evaluation of the Löf Residence, Denver, Colorado. Semiannual Progress Report, Jul 1 - Dec 31 '74". Solar Energy Appl. Lab, Colorado State Univ., Fort Collins, CO. 32 pp; 20 Jan ' 75.

Weingart, J. M.; Schoen, R., "Solar/Thermal Technologies and Technical Innovation in the US Construction Industry-Challenge to Commercialization". Proceedings of the Solar Heating and Cooling for Buildings Workshop, Washington, DC. Mar 21-23, '73. Part I: Technical Sessions, pp 153-163; Mar 173.

Weinstein, A.; Chen, C. S., Cooling by Solar Heat-Heating and Cooling System for Buildings". AIAA and AAS, Solar Energy for Earth Conference, Los Angeles, CA, Apr 21-24, '75, 8 pp; Apr 175.

Weinstein, A.; Chen, C. S., "Feasibility of Solar Heating and Cooling of Bulldings". Prof". Eng (Washington, DC); 44:No. 2, 28-32; Feb 74.

Weinstein, A.; Duncan, R.T., Jr.; Sherbin, W. C. "Lessons Learned from Atlanta (Towns) Solar Experiment". In "Sharing the Sun! Solar Technology in the Seventies. Vol. 3"; Böer, K. W. (Ed.). Pp 153-167; 1976.

Weinstein, A., "Social, Environmental, and Institutional Considerations: A Report by Westinghouse Electric Corporation". Solar Heating and Cooling of Buildings. Iachetta, F. A. (Ed.). NSF, Washington, DC, PP 96-102; 1975.

Weinstein, A., "Technical and Economic Considerations for Solar Heating and Cooling of Buildings: A Report by Westinghouse Electric Corporation". Solar Heating and Cooling of Buildings. Iachetta, F. A. (Ed.), pp 31-44. Washington, DC; NSF ; 1975.

Whitby, 0.,"Space Heating and Cooling Using Solar Energy". Conf. Paper. Unk. SRI (15 Apr 155). 15 pp. From SRI Solar Energy Technical Committee Meeting; (21 Apr 155); Apri1 155.

White, G. M.; Isaccs, G. W., "Evaluation of a Solar-Powered Cooling System for Livestock Shelters". Paper No. 60-821 from 1960 Winter Meeting of Am Soc of Agricultural Engl; Memphis, TN (Dec '60); Dec '60. 
White, G: M.; Isaccs, G. W. "Solar-Power Cooling for Livestock Shelters". Agricultural Eng.; 42: No. 11, 612-615; Nov '61.

Whitlow, E. P.; McNeely, L. A., "Absorption Air Conditioner". Refr. Engr.; 59, 38-43; 1951 .

Whitlow, E.: P.; Swearingen, J. S., "An Improved Absorption-Refrigeration Cycle". Paper Presented at Southern Texas AICHE Meeting; 1959.

Whitlow, E. P., "Relationship Between Heat Source Temperature, Heat Sink Temperature and Coefficient of Performance for Solar-Powered Absorption Air

Conditions". Paper Presented at ASHRAE Meeting, Dallas, Tex.; Feb '76.

Wilbur, D. W., Jr., "Review of Commercial Possibilities for Solar Heating and Cooling of Buildings". Solar Heating and Cooling of Buildings. Iachetta F. A. (Ed.). Washington, DC; NSF (1975); pp 148-150; 1975.

Wilbur, P. J.; Mitchell, C. E., "Solar Absorption Air Conditioning Alternatives". Solar Energy, Vol. 17, Jul '75. pp 193-199; Jul 175.

Williams, D. A.; et al., "Cooling Systems Based on Solar Regeneration". Refr. Engr. 66,33; Nov' 58.

Williams, J. R., "Comparative Evaluation of Solar, Fission, Fusion, and Fossil Energy Resources. Part I. Solar Energy". 1974.

Williams, J. R., "Solar Energy Technology and Applications". Ann Arbor Science Publishers, Inc., Ann Arbor, MI. 134 pp; 1974.

Williams, J. R.; Chen, C. S., "Solar Heating and Cooling". In Solar Energy for Earth, An AIAA Assessment. (A75-31267 14-44) New York, AIAA, Inc., 1975, pp $18-31 ; 1975$.

Williams, J. R.; Craig, J. I., "The Shenandoah Solar Community Center". In "Sharing the Sun! Solar Technology in the Seventies. Vol. 3"; Böer, K. W. (Ed.). pp 200-212; 1976.

Wilson, J. L., "Analysis of Solar Heating and Cooling of Buildings". ASHRAE J.; 17:No. 1, 72-6; Jan 175 .

Winn, C. B.; Johnson, G. R., "Dynamic Simulation for Performance Analysis of Solar Heated and Cooled Buildings". ASME Winter Annual Meeting, New York, NY Nov 17-22, '74. 9 pp; Nov' 74.

Winn, C. B.; Johnson, G. R.; Corder, T. E., "SIMSHAC-A Simulation Program for Solar Heating and Cooling of Buildings". Simulation, Vo1. 23, Dec "74, pp 165170; Dec '74.

Winn, C. B.; Hull, D., "Temperature Control for Solar Heating and Cooling of Buildings". AAS and AIAA Astrodynamics Specialist Conference, Nassau, Bahamas. Jul 28-30, '75. AAS Paper 75-105. $36 \mathrm{pp;} \mathrm{Jul} \mathrm{'75.}$ 
Wolf, M., "Solar Energy Residential System Modeling". Nat'l Center for Energy Management and Power, Univ. of Pennsyivania. Pp 463-475; [ND].

Wood, A. S., "Solar Air Conditioning with Fflm and Foam". Modern Plastics; 51 :No. 2, 43 ; Feb 174.

Wood, B. D.; Yellott, J. I., "Summary Analysis, NSF-RANN Phase $\emptyset$ Solar Heating and Cooling of Buildings". In 1975 Intn' 1 Solar. Energy Congress and Expo; pp 20-21. Rockville, MD; ISES; 1975. 
Yanagimachi, M., "How to Combine Solar Energy, Nocturnal Radiation Cooling, Radiant Panes System of Heating and Cooling, and Heat Pump to make a Complete Year Round Air Conditioning System". Conf. on the Use of Solar Energy: The Scientific Basis. Vo1. 3, pp 21-31. Tucson; Univ. of Arizona Press; 1958.

Yanagimachi, M., "Report on Two and a Half Years' Experimental Living in Yanagimachi Solar House II". Proceedings on UN Conf. on New Sources of Energy. Vol. 5, PP 233-247. New York; UN; 1964.

Yass, K.; Curtis, H. B., "Low-Cost, Air Mass 2 Solar Simulator". NASA-LRC, Cleveland, OH (NASA TM X-3059). 23 pp; Jun 74.

Yass, K.: Curtis, H. B., "Operational Performance of a Low Cost, Air Mass 2 Solar Simulator". NASA-LRC, Cleveland, OH (NASA TM X-71662). 10 pp; 1975.

Yellott, J. I., "Energy from Sun". Power Eng.; 61:No. 2; Feb '57.

Yellott, J. I., "Solar Energy: A Current Overview". Heating, Piping, Air Conditioning; pp 50-57; Jul 176.

Yellott, J. I. (Chairman), "Solar Energy Applications". ASHRAE, Inc.; New York, NY. 52 pp; 1974.

Yellott, J. I., "Solar Energy in the 1970's". Heating, Piping, Air Cond.; 47;No. 7, 31-37; Jul '75.

Yellott, J. I.; Macphee, C. W., "Solar Energy Utilization for Heating and Cooling". ASHRAE, Inc., New York; NY 26 pp; 1974.

Yellott, J. I., "Some Aspects of Solar-Energy Economics". ASME; New York. vp. ASME Paper 57-5A-60; 1957.

Yellott, J. I., "Utilization of Sun and Sky Radiation for Heating and Cooling of Buildings". ASHRAE, J.; 31-42 (Dec '73); Dec '73.

Young, M., "Solar Energy-The Physics of the Greenhouse Effect". Applied Optics, Vo1. 14, Jul '75, pp 1503-1508; Jul '75.

Yu, H. C.; Hankins, R. P. Jr., "Cooling a Light Industrial Building in Puerto Rico Using Solar Energy". AIAA and AAS, Solar Energy for Earth Conference, Los Angeles, CA, Apr 21-24, '75. AIAA 24 pp; Apr 17.

Yu, A.; Beiun, V. I.; et al., "Thermoelectric Pile for Household Air Conditioning". Geliotekhnika; Vol. 5, No. 4, pp 57-59; 1969. 